tef 40

AUن 22 "

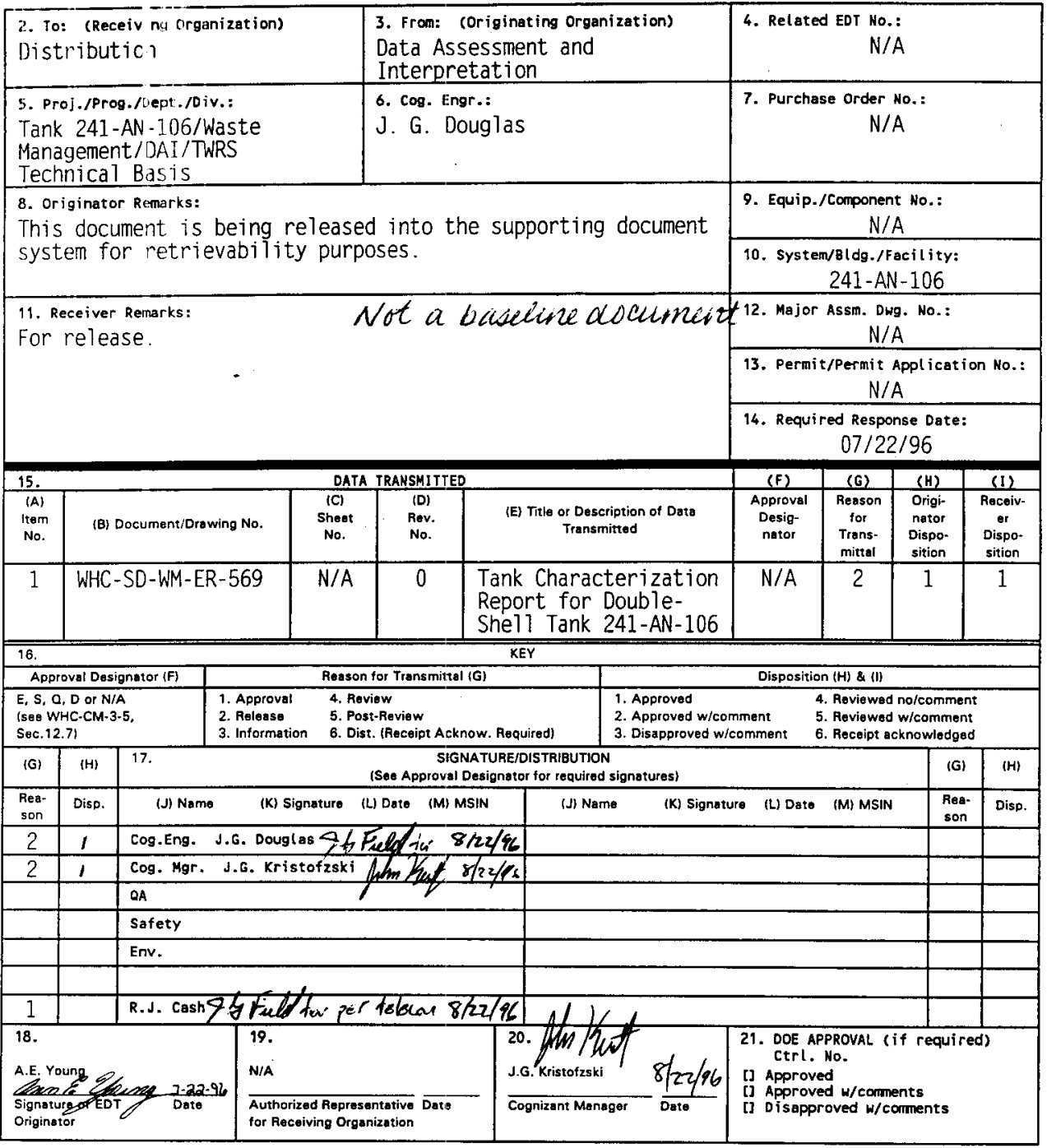

BD-7400-172-2(04/94) GEF097 


\title{
Tank Characterization Report for Double-Shell Tank 241-AN-106
}

\author{
J. G. Douglas
}

Westinghouse Hanford Company. Richland, WA 99352

U.S. Department of Energy Contract DE-AC06-87RL10930

EDT/ECN: EDT-617508

Org Code: 79400

B\&R Code: EW 3120074 Total Pages: 80 Ciit 8 aj/96

UC: 2070

Charge Code: N4G4D

Key words: Tank Characterization Report, TCR. Double-Shell Tank. Double-She11, DST, Tank 241-AN-106, Tank AN-106, AN-106, AN Farm

Abstract: This document summarizes the information on the historical uses, present status. and the sampling and analysis results of waste stored in Tank $241-\mathrm{AN}-106$. This report supports the requirements of Tri-Party Agreement Mi lestone M-44-09.

TRADEMARK OISCLAIMER. Reference herein to any specific commercial product, process, or service by trade name, trademark, manufacturer, or otherwise, does not necessarily constitute or imply its endorsement, recomendation, or favoring by the United States Goverment or any agency thereof or its contractors or subcontractors.

Printed in the United States of America. To obtain copies of this document, contact: WHC/BCS Document Control Services, P.O. Box 1970, Mailstop H6-08, Richland WA 99352, Phone (509) 372-2420; Fax (509) 376-4989.

Qnis Brader Relese Approval 8122196

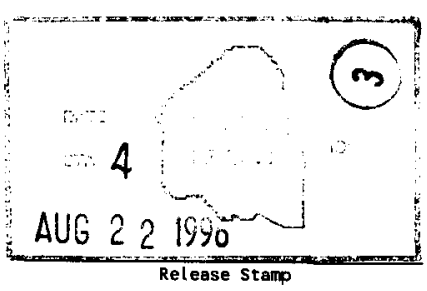

\section{Approved for Public Release}




\title{
Tank Characterization Report for Double-Shell Tank 241-AN-106
}

\author{
J. G. Douglas \\ Westinghouse Hanford Company \\ B. J. Morris \\ T. T. Tran \\ Los Alamos Technical Associates \\ Date Published \\ August 1996
}

Prepared for the U.S. Department of Energy

Assistant Secretary for Environmental Management

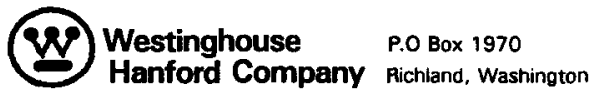

Management and Operations Contractor for the

U.S. Depertment of Energy under Contract DE-ACO6-87RL10930

Approved for public release, distribution is unlimited 


\section{EXECUTIVE SUMMARY}

This tank characterization report summarizes the information on the historical uses, current status, and sampling and analysis results of waste stored in double-shell underground storage tank 241-AN-106. This report supports the requirements of the Hanford Federal Facility Agreement and Consent Order, Milestone M-44-09 (Ecology et al. 1996).

Tank 241-AN-106 is one of seven double-shell tanks in the 200 East Area AN Tank Farm on the Hanford Site. The tank went into service in 1981, and received water from tank 241-AN-101. In 1983, the tank received concentrated phosphate waste and noncomplexed waste from tank $241-\mathrm{AW}-102$. In 1984 , the tank received a small volume of unknown waste. In 1993, waste was transferred from tank 241-AN-106 to tank 241-AP-102. In September 1994, tank 241-AN-106 received double-shell slurry feed waste from tank 241-AW-106. As of May 31, 1995, no additional recordable transfers into or out of the tank had been made (Hanlon 1996b).

A description of tank 241-AN-106 and its status are summarized in Figure ES-1 and Table ES-1. The tank has an operating capacity of $4,390 \mathrm{~kL}(1,160 \mathrm{kgal})$, and it presently contains 1,570 kL (415 kgal) of waste classified as double-shell slurry feed (Hanlon 1996b). The waste is estimated to be composed of $64 \mathrm{~kL}$ (17 kgal) of sludge and 1,510 kL (398 kgal) of supernatant liquid (Hanlon 1996b). The average tank temperature between July 1983 and March 1996 was $23.7^{\circ} \mathrm{C}\left(74.6^{\circ} \mathrm{F}\right)$, with a minimum of $14^{\circ} \mathrm{C}\left(58^{\circ} \mathrm{F}\right)$ and a maximum of 
Figure ES-1. Profile of Tank 241-AN-106.
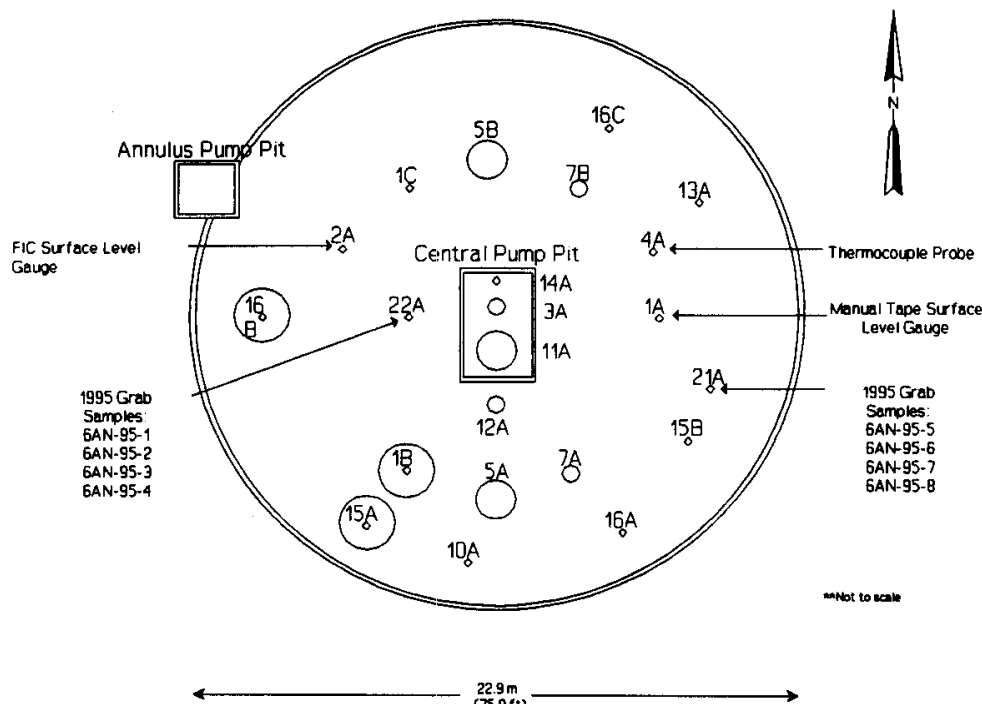

$(75.0 \mathrm{ft})$

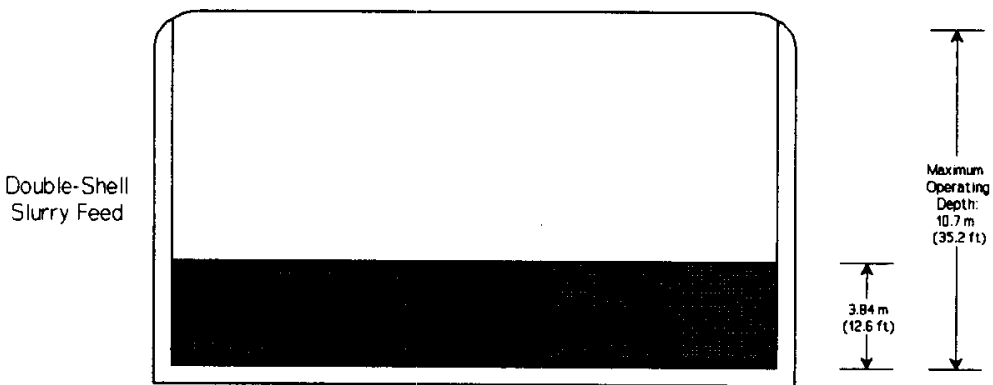

Total Tark Volume: $4,390 \mathrm{~kL}(1,460 \mathrm{kgol})$

Current Weste Volume (Decenter 1995): $1,580 \mathrm{KL}$ (417 kgal)

Sluog volume (Decenter 1995 ): $\quad$ G kL (17 kal)

Supernate Volum (December 4995): 1,510 kL (400 kgal) 
(966I) DHMs

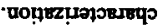

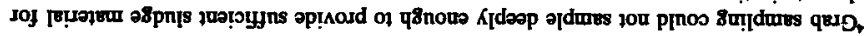

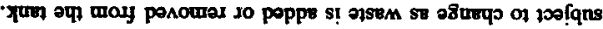

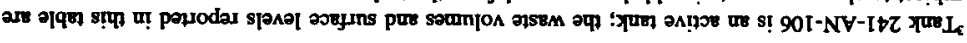

(q966I) поमㅏ $\mathrm{H}_{2}$

(8966 I) вотшен

:senoN

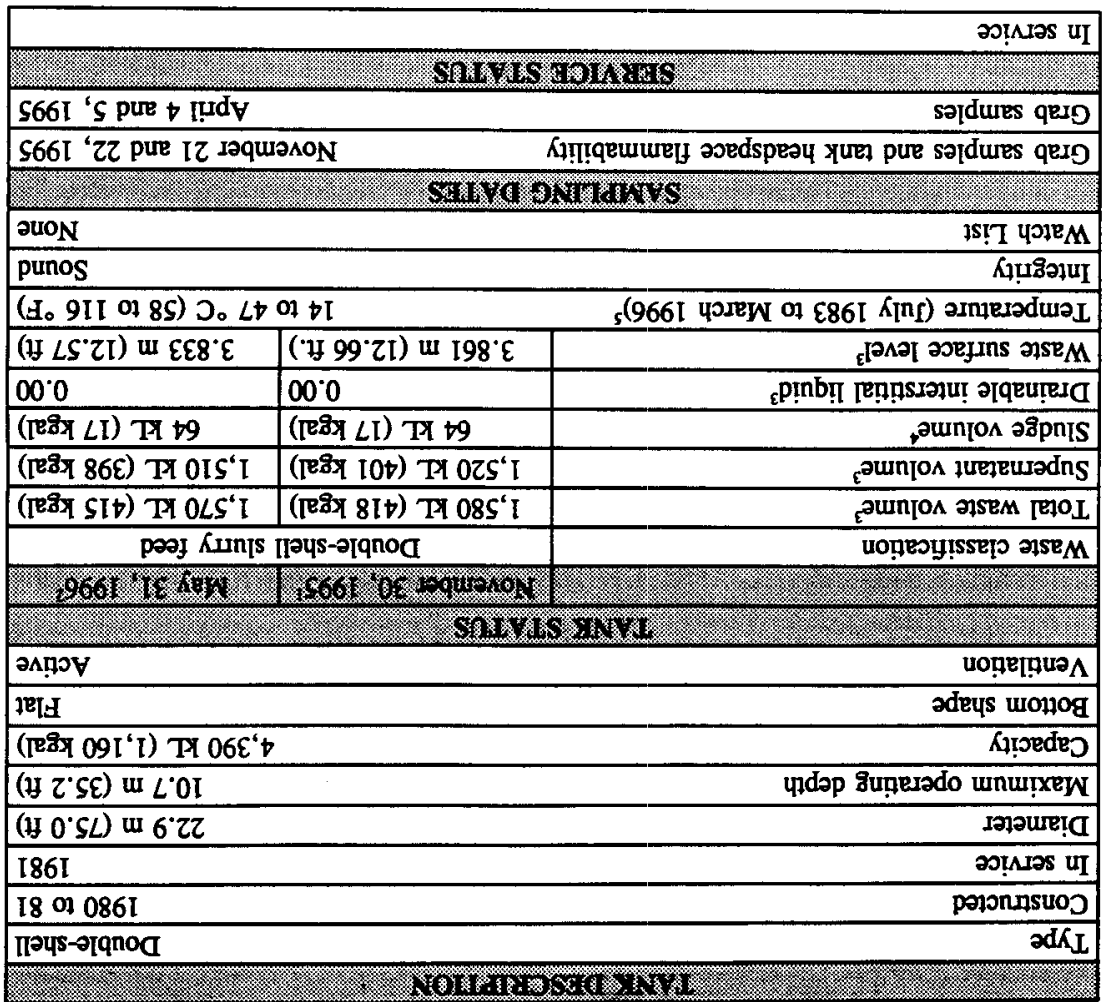

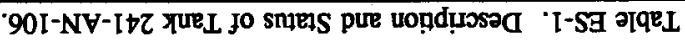


$47^{\circ} \mathrm{C}\left(116^{\circ} \mathrm{F}\right)$. Hanlon $(1996 \mathrm{~b})$ showed a waste level of $3.833 \mathrm{~m}(12.58 \mathrm{ft})$ as of May 31 , 1996.

This report summarizes the collection and analysis of eight grab samples taken in November 1995 . The sampling event was performed to satisfy the requirements of the Tank Safety Screening Data Quality Objective (Dukelow et al. 1995). The sampling and analyses were performed in accordance with the Tank 24I-AN-106 Grab Sampling and Analysis Plan (Conner 1995). Six grab samples were recovered from the supernatant layer in the tank. An attempt to obtain an additional two grab samples of the sludge layer on the tank bottom yielded supernate with less than a gram of solids; these two samples were taken $13 \mathrm{~cm}$ ( 5 in.) from the tank bottom. The sludge layer could not be sampled most likely because the sludge layer was too thin for the grab sampler to adequately penetrate and sample. Consequently, the characterization results do not reflect the composition of the sludge layer.

As required by the safety screening data quality objective (DQO), the grab samples were analyzed for moisture content using thermogravimetric analysis (TGA), for energetics content using differential scanning calorimetry (DSC), for total alpha activity using an alpha proportional counter, and for density. The DQO also required a determination of the flammability of tank headspace gases. This requirement was met by sampling the headspace prior to grab sampling. Finally, a total organic carbon (TOC) analysis was performed in an attempt to verify the type of waste in tank 241-AN-106. 
Table ES-2 summarizes the analytical results and, where applicable, the error associated with each result. These results apply only to the supernate because the sludge layer was not adequately sampled. For the supernate, which constitutes 96 percent of the waste volume in tank 241-AN-106, none of the safety screening DQO criteria were exceeded. No exothermic reactions were observed in any November 1995 grab samples. The average weight-percent water was 76.6 percent. The overall mean total alpha activity was $<0.00684 \mu \mathrm{Ci} / \mathrm{mL}$, far below the notification limit of $61.5 \mu \mathrm{Ci} / \mathrm{mL}$. The sludge layer, which forms only four percent of the tank waste volume, was not adequately sampled; therefore no assessment regarding the tank safety DQO can be made for it. Combustible gas meter readings of the vapor samples revealed that the concentration of flammable gases was 0 percent of the lower flammability limit (LFL), far less than the safety screening DQO limit of 25 percent of the LFL. Total organic carbon was determined to assist in verifying the type of waste in

Table ES-2. Tank 241-AN-106 Analytical Averages. ${ }^{1}$

\begin{tabular}{|c|c|c|}
\hline 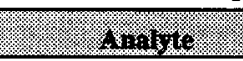 & 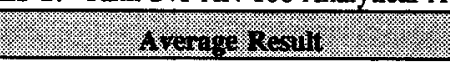 & 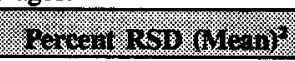 \\
\hline Total alpha activity & $<0.00684 \mu \mathrm{Ci} / \mathrm{mL}$ & $\mathrm{n} / \mathrm{a}$ \\
\hline Bulk density & $1.19 \mathrm{~g} / \mathrm{mL}$ & 0.63 percent \\
\hline Energetics & No exothermic reactions & $n / a$ \\
\hline Flammable gas & 0 percent of lower flammability limit & $\mathrm{n} / \mathrm{a}$ \\
\hline Percent water & 76.6 weight percent water & 1.10 percent \\
\hline TOC & $4,390 \mu \mathrm{g} \mathrm{C} / \mathrm{mL}$ & 15.3 percent \\
\hline
\end{tabular}

Notes:

$\mathbf{n} / \mathbf{a}=$ not applicable

'Esch (1996a)

${ }^{2}$ Percent relative standard deviation of the mean (average) result; $\%$ RSD $=100 \times$ standard deviation of the overall mean $\div$ overall mean value. 
tank 241-AN-106. However, without additional waste characterization, the TOC result of $4,390 \mu \mathrm{g} \mathrm{C} / \mathrm{mL}$ could support a waste designation of either dilute complexed or noncomplexed waste.

Statistical analysis of the analytical results suggests the supernate layer exhibits a slight vertical heterogeneity in percent water content. The tank shows a definite increase in grabsample dose rate with sample depth. This implies the concentration of beta/gamma-emitting radionuclides also increases with sample depth. Horizontally, the supernate appears to be fairly homogeneous.

Evidence from sludge weight measurements and the attempts to grab sample the sludge layer indicates that the sludge layer is about 13 to $16 \mathrm{~cm}$ (5 to $6 \mathrm{in}$.) deep. The increase in radionuclide concentration with depth implies that the sludge layer is likely to have a greater radionuclide concentration than the supernate. 


\section{CONTENTS}

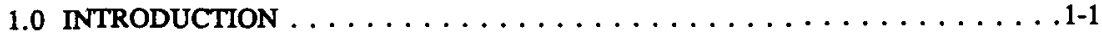

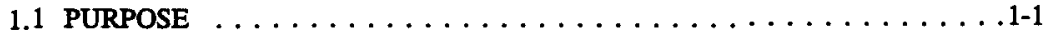

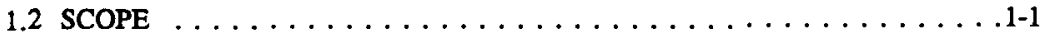

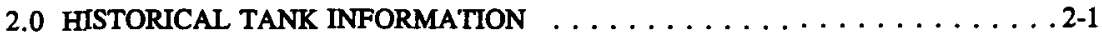

2.1 TANK STATUS $\ldots \ldots \ldots \ldots \ldots \ldots \ldots \ldots \ldots \ldots \ldots \ldots \ldots \ldots \ldots .2-1$

2.2 TANK DESIGN AND BACKGROUND $\ldots \ldots \ldots \ldots \ldots \ldots \ldots \ldots \ldots .2-1$

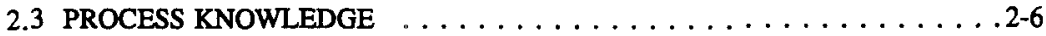

2.3.1 Waste Transfer History . . . . . . . . . . . . . 2-6

2.3.2 Historical Estimation of Tank Contents . . . . . . . . . . 2-6

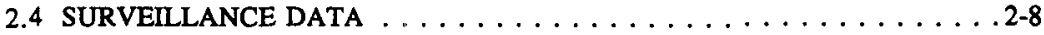

2.4.1 Surface Level . . . . . . . . . . . . . . . . . .2-8

2.4.2 Internal Tank Temperatures . . . . . . . . . . . . . 2-10

2.4.3 Tank 241-AN-106 Photographs . . . . . . . . . . . . . . . 2-10

3.0 TANK SAMPLING OVERVIEW $\ldots \ldots \ldots \ldots \ldots \ldots \ldots \ldots \ldots \ldots \ldots \ldots$ 3-1

3.1 DESCRIPTION OF SAMPLING EVENT $\ldots \ldots \ldots \ldots \ldots \ldots$. $\ldots \ldots \ldots$

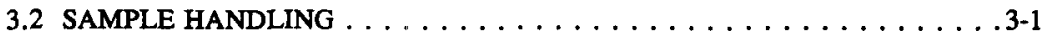

3.3 SAMPLE ANALYSIS $\ldots \ldots \ldots \ldots \ldots \ldots \ldots \ldots \ldots \ldots \ldots . \ldots \ldots$

3.4 DESCRIPTION OF APRIL 1995 GRAB SAMPLING EVENT . . . . . . . 3-4

4.0 ANALYTICAL RESULTS $\ldots \ldots \ldots \ldots \ldots \ldots \ldots \ldots \ldots \ldots \ldots \ldots \ldots \ldots$ 4-1

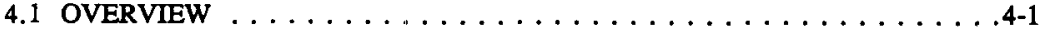

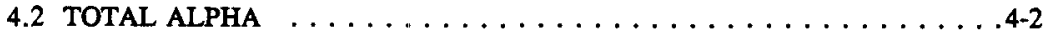

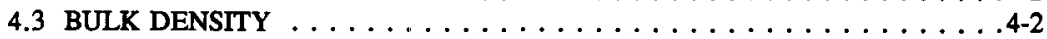

4.4 THERMAL ANALYSES $\ldots \ldots \ldots \ldots \ldots \ldots \ldots \ldots \ldots . \ldots \ldots$. . . . . . . . . .

4.4.1 Thermogravimetric Analysis . . . . . . . . . . . . 4-4

4.4.2 Differential Scanning Calorimetry . . . . . . . . . . . . 4-4

4.5 TANK HEADSPACE FLAMMABILITY $\ldots \ldots \ldots \ldots \ldots \ldots \ldots . . \ldots .4$

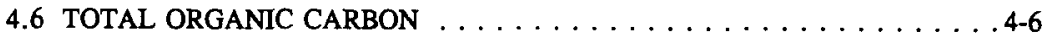

4.7 APRIL 1995 GRAB SAMPLE RESULTS . . . . . . . . . . . . . 4-7

5.0 INTERPRETATION OF CHARACTERIZATION RESULTS . . . . . . . . 5-1

5.1 ASSESSMENT OF SAMPLING AND ANALYTICAL RESULTS $\ldots \ldots \ldots$ 5-1

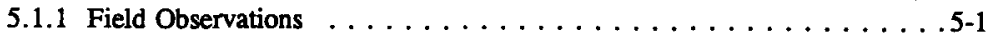

5.1 .2 Quality Control Assessment . . . . . . . . . . . . . . . 5-2

5.1.3 Data Consistency Checks . . . . . . . . . . . . . . . . . 5-2

5.2 COMPARISON OF HISTORICAL WITH ANALYTICAL RESULTS . . . . . 5-4

5.3 TANK WASTE PROFILE . . . . . . . . . . . . . . . . 5-4

5.4 COMPARISON OF TRANSFER HISTORY WITH ANALYTICAL RESULTS 
5.5 EVALUATION OF PROGRAM REQUIREMENTS . . . . . . . . 5-6

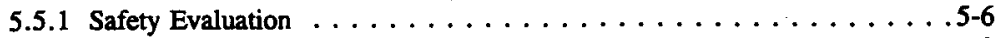

5.5.2 Verification of Tank Waste Classification $\ldots \ldots \ldots \ldots \ldots \ldots .5$

6.0 CONCLUSIONS AND RECOMMENDATIONS $\ldots \ldots \ldots \ldots \ldots \ldots$ 6-1

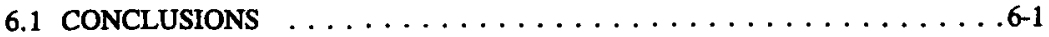

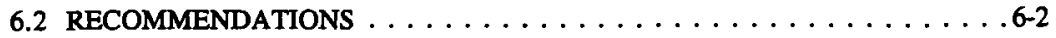

7.0 REFERENCES $\ldots \ldots \ldots \ldots \ldots \ldots \ldots \ldots \ldots \ldots \ldots \ldots \ldots \ldots \ldots$

\section{APPENDICES}

A CALCULATED COMPOSITION OF TANK 241-AN-106 SUPERNATE . . . . . A A-1

B STATISTICAL RESULTS FOR DOUBLE-SHELL TANK 241-AN-106 . . . . . B B-1

\section{LIST OF FIGURES}

2-1 Riser Configuration for Tank 241-AN-106 . . . . . . . . . . . 2-4

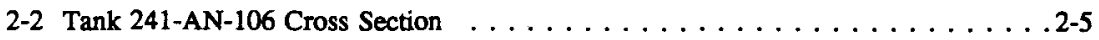

2-3 Tank 241-AN-106 Level History $\ldots \ldots \ldots \ldots \ldots \ldots \ldots \ldots \ldots . . \ldots \ldots$

2-4 Tank 241-AN-106 Weekly High Temperature Plot . . . . . . . . . . 2-11 


\section{LIST OF TABLES}

2-1 Tank Contents Summary as of May $31,1996 \ldots \ldots \ldots \ldots \ldots \ldots .2$

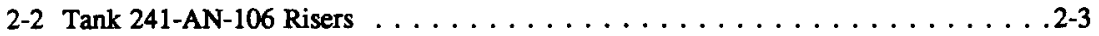

2-3 Summary of Tank 241-AN-106 Waste Transfer History $\ldots \ldots \ldots \ldots \ldots$ 2-7

3-1 Integrated Data Quality Objective Requirements for Tank 241-AN-106 . . . . . . 3-2

3-2 Sample Identification Numbers, Sample Volumes, and Dose Rates . . . . . . . . 3-3

3-3 Tank 241-AN-106 Sample Descriptions $\ldots \ldots \ldots \ldots \ldots \ldots \ldots \ldots$ 3-3

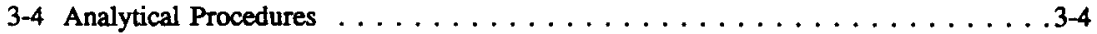

4-1 Analytical Data Tables $\ldots \ldots \ldots \ldots \ldots \ldots \ldots \ldots \ldots \ldots \ldots$ 4-1

4-2 Total Alpha Activity Results for Tank 241-AN-106 . . . . . . . . . 4-3

4-3 Density Results for Tank $241-A N-106 \ldots \ldots \ldots \ldots \ldots \ldots$ 4-3

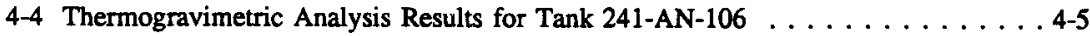

4-5 Differential Scanning Calorimetry Results for Tank 241-AN-106 . . . . . . . . 4-6

4-6 Total Organic Carbon Results for Tank 241-AN-106 . . . . . . . . . . . . 4-7

4-7 Free Hydroxide Concentration in Mixtures of Supernate from

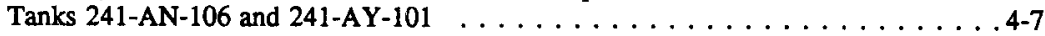

5-1 Safety Screening Data Quality Objective Decision Variables and Criteria . . . . . 5-8 


\section{LIST OF TERMS}

$\begin{array}{ll}\text { ANOVA } & \text { analysis of variance } \\ \mathrm{Ci} / \mathrm{g} & \text { curies per gram } \\ \mathrm{DQO} & \text { data quality objective } \\ \mathrm{DSC} & \text { differential scanning calorimetry } \\ \mathrm{ft} & \text { feet } \\ \mathrm{g} \mathrm{C} / \mathrm{L} & \text { grams of carbon per liter } \\ \mathrm{g} / \mathrm{L} & \text { grams per liter } \\ \mathrm{g} / \mathrm{mL} & \text { grams per milliliter } \\ \mathrm{HTCE} & \text { Historical Tank Content Estimate } \\ \mathrm{ID} & \text { identification } \\ \mathrm{in} & \text { inches } \\ \mathrm{J} / \mathrm{g} & \text { joules per gram } \\ \mathrm{kgal} & \text { kilogallons } \\ \mathrm{kL} & \text { kiloliters } \\ \mathrm{kPa} & \text { kilopascals } \\ \mathrm{LEL} & \text { lower explosive limit } \\ \mathrm{LFL} & \text { lower flammability limit } \\ \mathrm{m} & \text { meters } \\ \mathrm{mg} & \text { milligrams } \\ \mathrm{mL} & \text { milliliters } \\ \mathrm{mR} / \mathrm{hr} & \text { milliroentgens per hour } \\ \mathrm{NFPA} & \text { National Fire Protection Association } \\ \mathrm{ppm} & \text { parts per million } \\ \mathrm{REML} & \text { restricted maximum likelihood estimate } \\ \mathrm{RSD} & \text { relative standard deviation } \\ \mathrm{SAP} & \text { sampling and analysis plan } \\ \mathrm{TGA} & \text { thermogravimetric analysis } \\ \mathrm{TIC} & \text { total inorganic carbon } \\ \mathrm{TOC} & \text { total organic carbon } \\ \mathrm{WVR} & \text { waste volume reduction } \\ { }^{\circ} \mathrm{C} & \text { degrees Celsius } \\ { }^{\circ} \mathrm{F} & \text { degrees Fahrenheit } \\ \mu \mathrm{Ci} / \mathrm{mL} & \text { microcuries per milliliter } \\ \mu \mathrm{g} / \mathrm{mL} & \text { micrograms per milliliter } \\ \mu \mathrm{g} \mathrm{C} / \mathrm{mL} & \text { micrograms of carbon per milliliter } \\ \Delta \mathrm{H} & \text { change in enthalpy } \\ & \end{array}$




\subsection{INTRODUCTION}

This tank characterization report provides an overview of double-shell tank 241-AN-106 and its waste contents. It provides estimated concentrations and inventories for the waste components based on the latest sampling and analysis activities and background tank information. The characterization of tank 241-AN-106 is based on the results of eight grab samples taken in November 1995. Results from September 1994 and April 1995 samples are also provided for information purposes.

Tank 241-AN-106 is still in service and may continue to transfer or receive waste. Consequently, the composition of the tank waste may change depending on the waste types received. The concentration and inventory values reported in this document reflect best estimates based on the characterization results from the November 1995 samples. This report supports the requirements of the Hanford Federal Facility Agreement and Consent Order, Milestone M-44-09 (Ecology et al. 1996).

\subsection{PURPOSE}

The purpose of this report is to summarize information about the use and contents of tank 241-AN-106. When possible, this information will be used to assess issues associated with safety, operations, environmental, and process development activities. This report also serves as a reference point for more detailed information about tank 241-AN-106.

\subsection{SCOPE}

The November 1995 grab sampling event for tank 241-AN-106 supported the evaluation of the tank waste given in the Tank Safety Screening Data Quality Objective (Dukelow et al. 1995). Five analyses were performed on the recovered waste as directed in the Tank 241-AN-106 Grab Sampling and Analysis Plan (Conner 1995) to verify the tank's nonWatch List status and to identify any possible tank waste safety issues. These analyses included DSC to evaluate fuel level and energetics, TGA to determine moisture content, and total alpha activity analysis to evaluate criticality potential. Supernate density was determined for use in criticality calculations and to enable conversion of the tank waste constituent inventory from a volume to a mass basis. A TOC analysis was also performed in an attempt to verify the waste type in tank 241-AN-106. As required by the safety screening DQO, the flammability of the tank headspace gases was measured. 
WHC-SD-WM-ER-569 Rev. 0

This page intentionally left blank. 


\subsection{HISTORICAL TANK INFORMATION}

This section describes tank 241-AN-106 based on historical information. The first part details the current condition of the tank. This is followed by discussions of the tank's background, transfer history, and the process sources that contributed to the tank waste. Events that may be related to tank safety issues, such as potentially hazardous tank contents or off-normal operating temperatures, are included. The final part summarizes available surveillance data for the tank. Leak detection instruments in the tank annulus are used to determine tank integrity (leaks). Liquid and solid level data are used to confirm the observations of the leak detection instruments and to provide clues to internal activity in the waste layers in the tank. Temperature data are provided to evaluate the heat generating characteristics of the waste.

\subsection{TANK STATUS}

As of May 31, 1996, tank 241-AN-106 contained 1,570 kL (415 kgal) of waste classified as double-shell slurry feed (Hanlon 1996b). The liquid volume was determined using a combination of a Food Instrument Corporation automatic surface level gauge and a manual tape surface level gauge. The solids volume was determined using a sludge level measurement device. The volume of the waste phases found in the tank are shown in Table 2-1.

Tank 241-AN-106 is a double-shell tank that is used as a concentrated waste holding tank. This tank is actively ventilated through riser 111 (7B) and is categorized as sound. All monitoring systems were in compliance with documented standards as of May 31, 1996 (Hanlon 1996b).

\subsection{TANK DESIGN AND BACKGROUND}

The AN Tank Farm, the newest generation double-shell design tank farm, was built between 1980 and 1981 . The tank farm consists of seven, type 100 series, $4,390 \mathrm{~kL}(1,160 \mathrm{kgal})$ tanks. These tanks were designed for a maximum fluid temperature of $177^{\circ} \mathrm{C}\left(350^{\circ} \mathrm{F}\right)$ (Brevick et al. 1995a). Tank 241-AN-106 has 22 risers ranging from $10 \mathrm{~cm}$ (4 in.) to 1.07 $\mathrm{m}(3.5 \mathrm{ft})$ in diameter that provide surface-level access to the underground tank and 37 risers that provide access to the annulus. Four risers are classified as spares: three $10 \mathrm{~cm}(4 \mathrm{in}$.) risers (numbers 125, 131, and 155) and one $30 \mathrm{~cm}(1 \mathrm{ft}$ ) riser (number 112). 
Table 2-1. Tank Contents Summary as of May 31, 1996.1.2

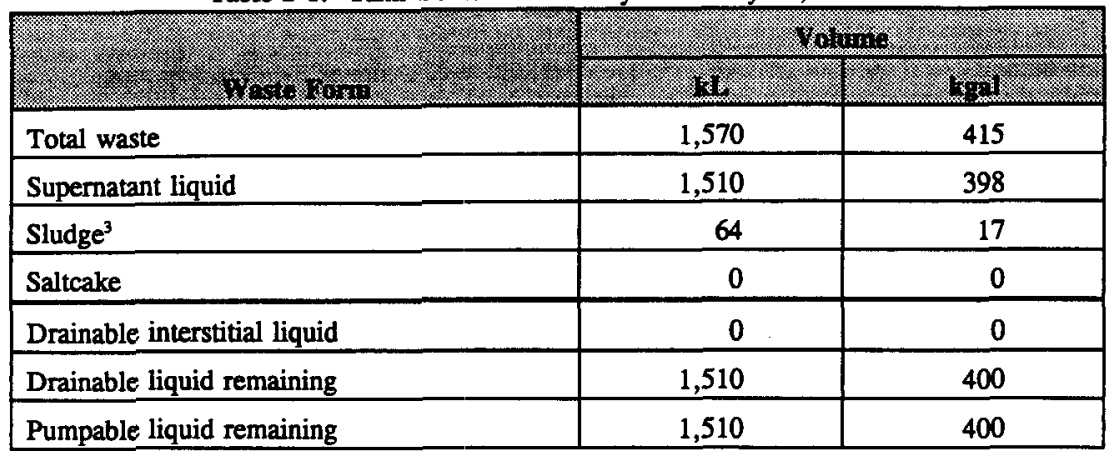

Notes:

'Hanlon (1996b)

'Tank 241-AN-106 is an active tank; the waste volumes and surface levels reported in this table are subject to change as waste is added or removed from the tank.

${ }^{3}$ Grab samples taken approximately $13 \mathrm{~cm}$ (5 in.) from the tank bottom could not provide sufficient sludge material for characterization. The sludge volume of $64 \mathrm{~kL}$ (17 kgal) from Table 2-1 corresponds to a sludge thickness of about $16 \mathrm{~cm}$ (6 in.).

Tank 241-AN-106 is constructed of 46-cm (1.5-ft)-thick concrete walls and a 38-cm (1.25-ft)-thick concrete dome. The primary (inner) carbon-steel liner is $22.9 \mathrm{~m} \mathrm{(75} \mathrm{ft)} \mathrm{in}$ diameter; the liner bottom is $1.3 \mathrm{~cm}(0.5 \mathrm{in}$.) thick, and the lower portion of the sides is $1.9 \mathrm{~cm}(0.75 \mathrm{in}$.) thick. The upper portion of the sides is $1.3 \mathrm{~cm}(0.5 \mathrm{in}$.) thick, and the dome liner is $0.95-\mathrm{cm}(0.375$-in.)-thick steel. The primary liner is heat treated and stress relieved. The secondary (outer) liner is made of 0.95 -cm $(0.375$-in.)-thick carbon steel. The secondary liner is not heat-treated. This tank has a flat bottom with a maximum operating depth of $10.7 \mathrm{~m}(35.2 \mathrm{ft})$. The tank is set on an insulated, reinforced concrete foundation. There is a grid of drain slots in the concrete beneath the secondary steel liner bottom. The grid's function is to collect waste that may leak from the tank and divert it to a leak detection well. Coatings and sealants were applied at the time of construction to prevent leaks and intrusions.

Table 2-2 shows a list of risers (not annulus risers) including size and typical use.

Figure 2-1 shows a plan view vi the riser configuration. Figure 2-2 shows a tank cross section of the approximate wasce level and a schematic of the tank equipment. 
Table 2-2. Tank 241-AN-106 Risers., ${ }^{1,2}$

\begin{tabular}{|c|c|c|c|}
\hline (1) & $\sin _{\sin 20}$ & 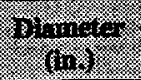 & (2) \\
\hline 102 & $1 A$ & 4 & Sludge measurement port, manual tape \\
\hline 103 & 1B & 4 & Sludge measurement port, protective concrete pad \\
\hline 101 & $1 \mathrm{C}$ & 4 & Sludge measurement port \\
\hline 104 & $2 A$ & 4 & Liquid level, level indicating transmitter \\
\hline 105 & $3 A$ & 12 & Supernatant pump, central pump pit (pit) \\
\hline 106 & 4A & 4 & Thermocouple tree \\
\hline 108 & $5 \mathbf{A}$ & 42 & Manhole, below grade \\
\hline 107 & 5B & 42 & Manhole, below grade \\
\hline 112 & $7 \mathrm{~A}$ & 12 & Spare \\
\hline 111 & $7 \mathrm{~B}$ & 12 & Tank ventilation \\
\hline 125 & $10 A$ & 4 & Spare \\
\hline 126 & $11 \mathrm{~A}$ & 42 & Slurry distributor, central pump pit (pit) \\
\hline 127 & $12 \mathrm{~A}$ & 12 & Observation port, spare \\
\hline 128 & $13 \mathrm{~A}$ & 4 & Tank pressure \\
\hline 129 & $14 A$ & 4 & Supernate return, central pump pit (pit) \\
\hline 131 & $15 \mathrm{~A}$ & 4 & Spare, protective concrete pad \\
\hline 130 & $15 B$ & 4 & High liquid level sensor \\
\hline 134 & $16 \mathrm{~A}$ & 4 & Sludge measurement port \\
\hline 132 & $16 \mathrm{~B}$ & 4 & Sludge measurement port, protective concrete pad \\
\hline 133 & $16 \mathrm{C}$ & 4 & Sludge measurement port \\
\hline 155 & $21 \mathrm{~A}$ & 4 & Spare \\
\hline 156 & $22 \mathrm{~A}$ & 4 & Sludge measurement port \\
\hline
\end{tabular}

Notes:

'Alstad (1992) and WHC (1994, 1995b, and 1995c)

${ }^{2}$ Annulus risers are not included in this table.

${ }^{3}$ Denotes January 20, 1995 Engineering Change Notice 613266 made against the reference drawings. 
Figure 2-1. Riser Configuration for Tank 241-AN-106.

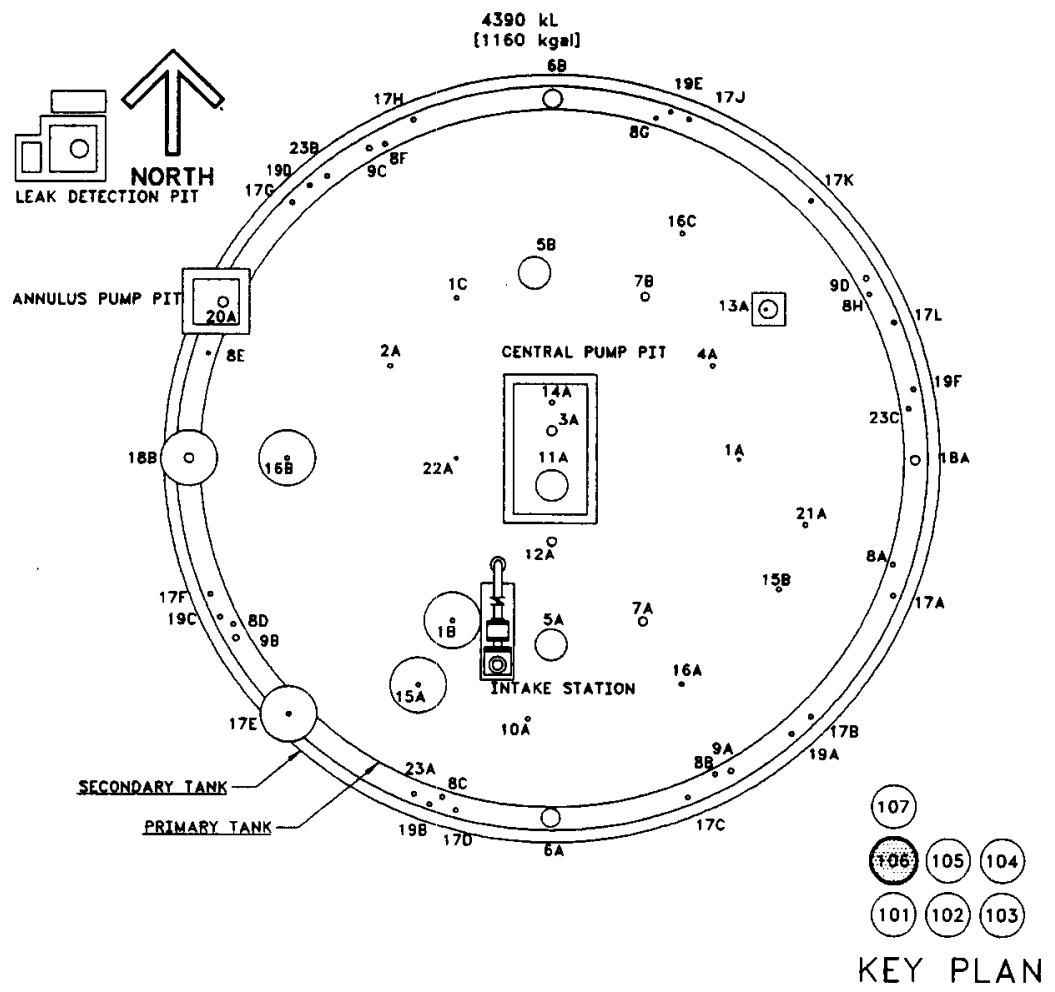


Figure 2-2. Tank 241-AN-106 Cross Section.

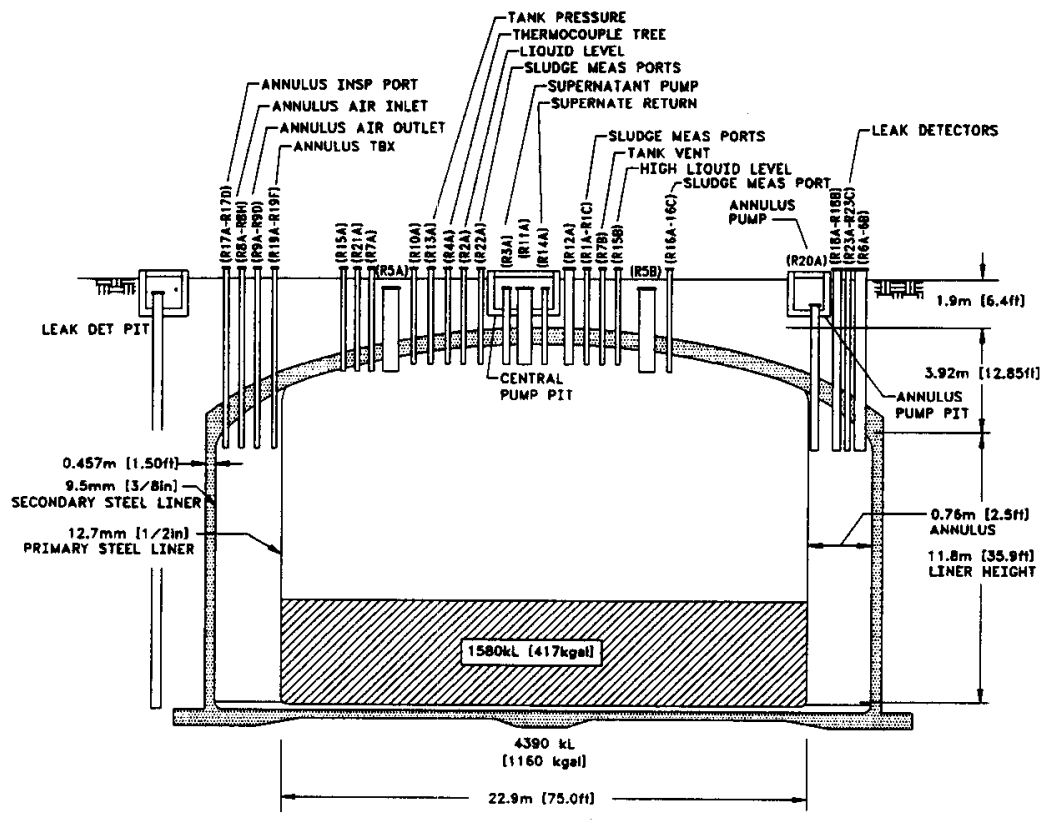




\subsection{PROCESS KNOWLEDGE}

These sections provide the transfer history of tank 241-AN-106 and describe the process wastes received.

\subsubsection{Waste Transfer History}

In 1981, tank 241-AN-106 went into service and received water from tank 241-AN-101. In 1983, tank 241-AN-106 received concentrated phosphate waste and dilute noncomplexed waste from tank 241-AW-102. In 1984, a small amount of waste (originating from an unknown source) was directed to tank 241-AN-106. In 1992, the majority of the waste in the tank was transferred to tank 241-AP-102, leaving only $87 \mathrm{~kL} \mathrm{(23} \mathrm{kgal).} \mathrm{The} \mathrm{last} \mathrm{waste}$ receipt was $1,510 \mathrm{~kL}$ (400 kgal) in September 1994. This transfer, which consisted of waste classified as double-shell slurry feed from tank 241-AW-106, was in part the product of the 242-A Evaporator 94-1 Campaign. As of May 31, 1995, no additional recordable waste transfers into or out of the tank were made (Hanlon 1996b). After the September 1994 waste transfer, the tank contained approximately $1,600 \mathrm{~kL}$ (423 kgal) of waste. The waste volume estimate as of May 31,1995 , was $1,570 \mathrm{~kL}$ (415 kgal). The difference between the $1,600 \mathrm{~kL}$ and $1,570 \mathrm{~kL}$ values may be attributed to evaporative water loss caused by the tank's active ventilation system. Tank 241-AN-106 is currently active and is considered a concentrated waste holding tank; the waste volumes and surface levels reported in this tank characterization report are subject to change as waste is added or removed from the tank. Table 2-3 summarizes the waste transfer history for tank 241-AN-106.

\subsubsection{Historical Estimation of Tank Contents}

Normally, an estimate of the current tank contents based on historical transfer and predicted waste stream composition data is provided by the Historical Tank Content Estimate for the Southeast Quadrant of the Hanford 200 East Areas (Brevick et al. 1995a). However, the historical tank content estimate (HTCE) for tank 241-AN-106 is based on data that extend only through the first quarter of 1994 (Agnew 1995) when the tank contained about $87 \mathrm{~kL}$ (23 kgal) of concentrated phosphate waste. Since the first quarter of 1994, a transfer of $1,510 \mathrm{~kL}(400 \mathrm{kgal})$ of double-shell slurry feed waste was received in September 1994; therefore, the HTCE is not applicable. 
Table 2-3. Summary of Tank 241-AN-106 Waste Transfer History. ${ }^{1}$

\begin{tabular}{|c|c|c|c|c|}
\hline \multirow{2}{*}{ 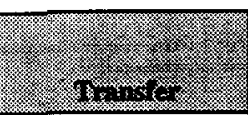 } & \multirow{2}{*}{ 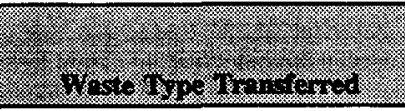 } & \multirow[b]{2}{*}{ 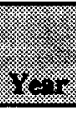 } & \multicolumn{2}{|c|}{ 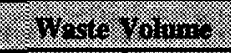 } \\
\hline & & & 18 & $\sqrt{3} \cdot 1$ \\
\hline From 241-AN-101 & Water & 1981 & 11 & 3 \\
\hline From 241-AW-102 & $\begin{array}{l}\text { Concentrated phosphate } \\
\text { waste/dilute noncomplexed waste }\end{array}$ & 1983 & 3,929 & 1,038 \\
\hline From unknown & $\begin{array}{l}\text { Unknown/concentrated phosphate } \\
\text { waste }\end{array}$ & 1984 & 45 & 12 \\
\hline To 241-AP-102 & $\begin{array}{l}\text { Concentrated phosphate } \\
\text { waste/dilute noncomplexed waste }\end{array}$ & 1993 & 3,740 & 987 \\
\hline From 241-AW-106 & Double-shell slurry feed ${ }^{2}$ & 1994 & 1,510 & 400 \\
\hline
\end{tabular}

Note:
${ }^{1}$ Agnew et al. (1995)
'TOC results from the November 1995 samples could also support alternative classifications of dilute complexed or noncomplexed waste; additional analyses are required to determine the actual waste classification of the supernate in tank 241-AN-106.

While the HTCE may not be applicable, other data exist that may be used to estimate the tank contents. Surface level and sludge level measurements suggest that tank 241-AN-106 contains two distinct layers: (1) a bottom layer consisting of approximately $64 \mathrm{~kL}$ (17 kgal) of solids of unknown composition, and (2) a supernate layer consisting of approximately $1,510 \mathrm{~kL}$ (398 kgal) of waste classified as double-shell slurry feed (Hanlon 1996b). Welsh and Hendrickson (1991) discuss the contents of tank 241-AN-106 prior to the waste transfer from tank 241-AN-106 to tank 241-AP-102, but they do not address the composition of any solids remaining at the bottom of tank 241-AN-106.

The supernate composition of tank 241-AN-106 may be predicted based on analyses of the two major sources that comprise the supernate layer in the tank. The supernate layer in tank 241-AN-106 is derived in part from the 242-A Evaporator 94-1 Campaign product (Guthrie 1994) and dilute noncomplexed waste from tank 241-AW-106 (DiCenso et al. 1994). In June 1994, about $1,160 \mathrm{~kL}$ (306 kgal) of the campaign $94-1$ product was transferred to tank 241-AW-106 which already contained 1,600 kL (423 kgal) of dilute noncomplexed waste (Hanlon 1994). In September 1994, about $1,510 \mathrm{~kL}$ (400 kgal) of supernate, including the campaign 94-1 product, was transferred from tank 241-AW-106 to tank 241-AN-106. 
DiCenso et al. (1994) report analytical data for tank 241-AW-106 prior to the addition of the campaign 94-1 product, and Miller (1996) reports the analytical results for the campaign 94-1 product. Appendix A summarizes the analytical results from these two waste sources and, using certain assumptions, attempts to predict the composition of the current contents of tank 241-AN-106 based on the two sources. The information in Appendix $A$ is provided as background information only; no decisions regarding the waste in tank 241-AN-106 should be based on Appendix A data.

\subsection{SURVEILLANCE DATA}

Tank 241-AN-106 surveillance consists of surface level measurements (liquid and solid) and temperature monitoring inside the tank (waste and headspace). The tank annulus is equipped with leak detection instrumentation consisting of continuous air monitors and conductivity probes (Johnson 1995). Surveillance data provide the basis for determining tank integrity. For double-shell tanks, the leak detection instruments are the primary means of detecting a leak from the primary tank; liquid level measurements may be used to confirm a possible leak detected from the annulus instruments (Johnson 1995). No occurrence reports have been written against tank 241-AN-106 that would indicate a leak from the primary tank. Solid level measurements indicate physical changes and consistency of the solid layers of a tank.

\subsubsection{Surface Level}

The surface level of the waste is monitored with a Food Instrument Corporation gauge and a manual tape. Hanlon (1996b) shows a waste level of $3.833 \mathrm{~m}(12.58 \mathrm{ft})$ as of May 31 , 1996. Figure 2-3 shows a graph of the volume measurements and level history for tank 241-AN-106.

During 1983 , additions of $3,929 \mathrm{~kL}(1,038 \mathrm{kgal})$ of concentrated phosphate waste from

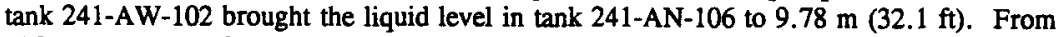
1984 to the time of the waste transfer from tank 241-AN-106 to tank 241-AP-102 in 1992, the liquid level showed a gradual decline. This decline was caused by evaporation and cooling of the waste as a result of the tank's active ventilation system (Brevick et al. 1995a). The negative-going "spike" visible in Figure 2-3 during the first quarter of 1984 apparently was caused by an error in the data used to prepare the figure; examination of weekly surface level data showed no such decrease during that time (WHC 1996).

As a result of a waste transfer to tank 241-AP-102 during November and December 1992,

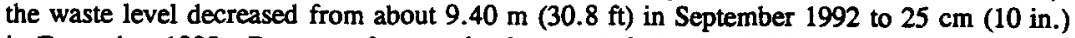
in December 1992. Because of a transfer from tank 241-AW-106 in September 1994, the waste level increased to its current level. In summary, fluctuations in tank 241-AN-106 
Figure 2-3. Tank 241-AN-106 Level History.

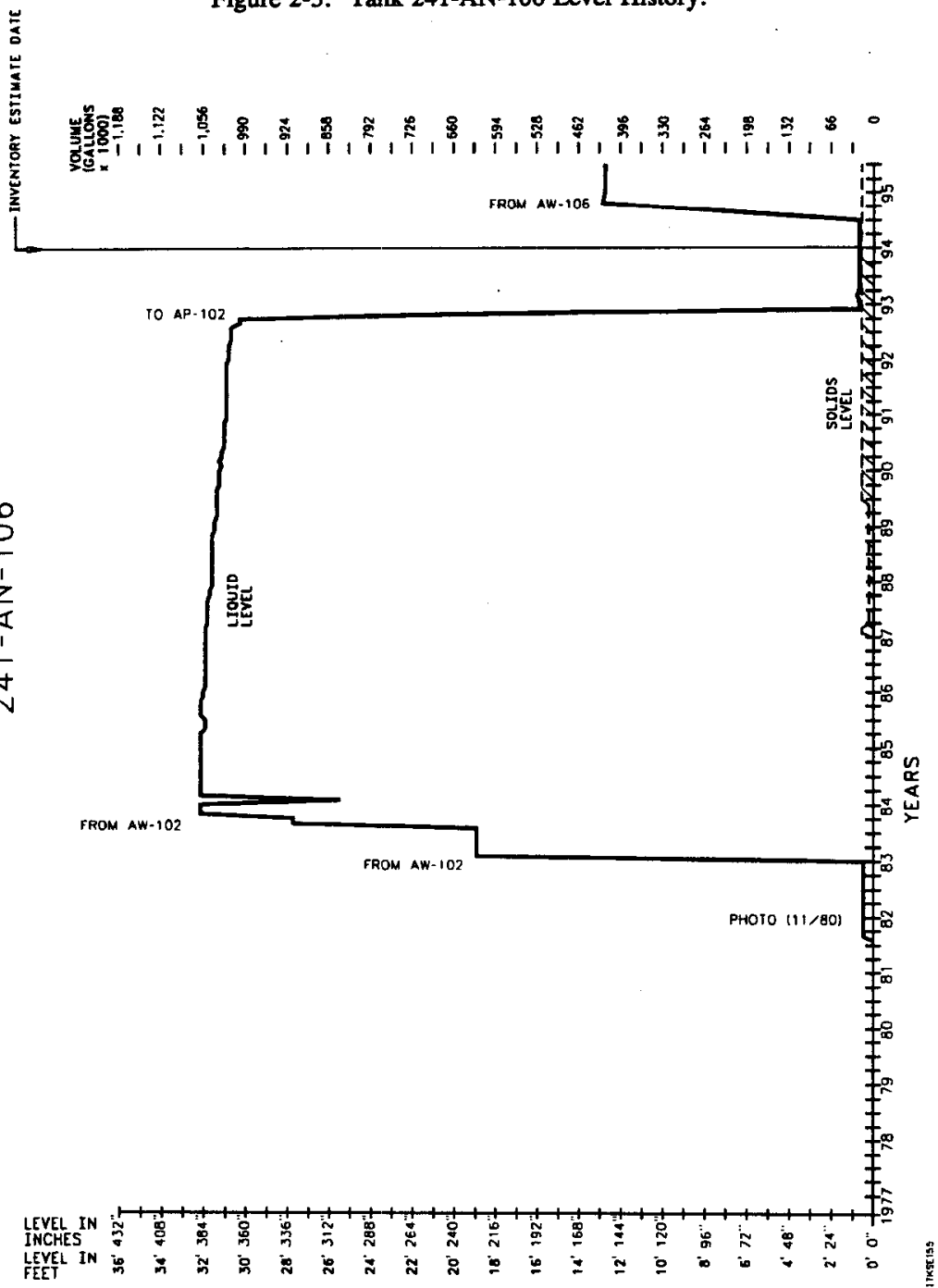


surface levels are attributed to tank waste transfers and evaporation and not to leaks from the tank to the environment.

\subsubsection{Internal Tank Temperatures}

Tank 241-AN-106 has a single thermocouple tree with 18 thermocouples to monitor the waste temperature through riser $4 A$. Thermocouple TE-106-AN-36 is $10 \mathrm{~cm}(3.9 \mathrm{in}$.) above the tank bottom. Thermocouples TE-106-AN-37 through TE-106-AN-51 are at $61 \mathrm{~cm}(2 \mathrm{ft})$ intervals above thermocouple TE-106-AN-36. Thermocouples TE-106-AN-52 and TE-106-AN-53 are at $1.20 \mathrm{~m}(4 \mathrm{ft})$ intervals above thermocouple TE-106-AN-51.

Figure 2-4 is a graph of the weekly high temperature for tank 241-AN-106 from 1983 through January 1996. The high temperature on March 14,1996 , was $21^{\circ} \mathrm{C}\left(70^{\circ} \mathrm{F}\right)$; the low was $17.5^{\circ} \mathrm{C}\left(63.5^{\circ} \mathrm{F}\right)$. From July 1983 through March 1996 , the average temperature was $23.7^{\circ} \mathrm{C}\left(74.6^{\circ} \mathrm{F}\right)$, the maximum temperature was $47^{\circ} \mathrm{C}\left(116^{\circ} \mathrm{F}\right)$, and the minimum temperature was $14^{\circ} \mathrm{C}\left(58^{\circ} \mathrm{F}\right)$. Figure $2-4$ also shows a temperature "spike" of $35^{\circ} \mathrm{C}$ $\left(95^{\circ} \mathrm{F}\right)$ in September 1994 . The spike was caused by the transfer of thermally warm product from the 242-A Evaporator 94-1 Campaign from tank 241-AW-106.

Temperature data from the Computer Automated Surveillance System is available for 17 of 18 thermocouples for July 1983 to June 1991. Temperature data from the Surveillance Analysis Computer System are available for all thermocouples from January 1990 to June 1995. Both data sources have several small breaks in the temperature data sets. Brevick et al. (1995b) contains plots of individual thermocouple readings for tank 241-AN-106.

\subsubsection{Tank 241-AN-106 Photographs}

The most recent tank photograph was taken in July 1994 prior to the $1,510 \mathrm{~kL}$ (400 kgal) waste transfer in September 1994. Therefore, the available tank photographs do not accurately represent the waste in tank 241-AN-106, and they are not reproduced here. 
Figure 2-4. Tank 241-AN-106 Weekly High Temperature Plot.

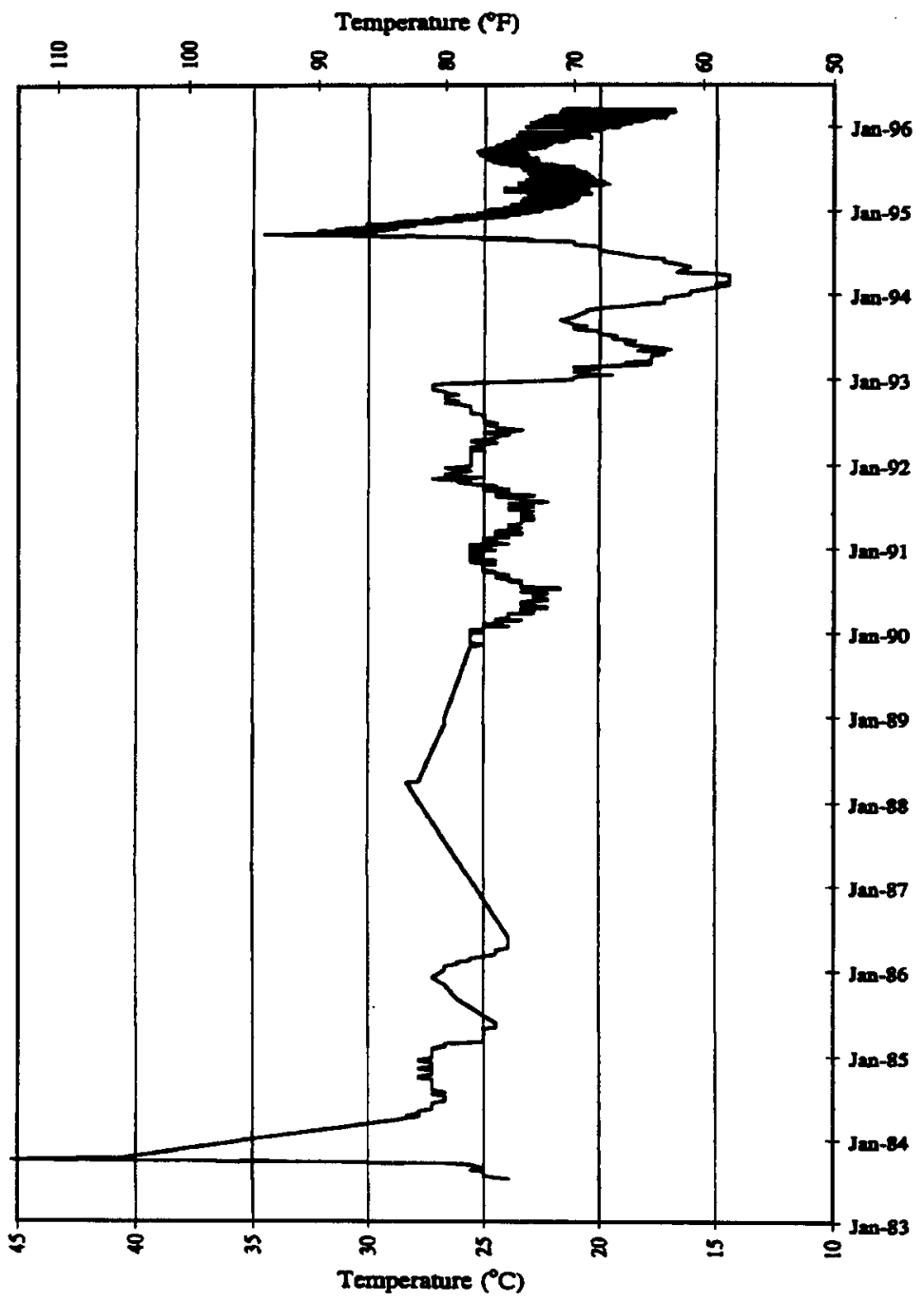


WHC-SD-WM-ER-569 Rev. 0

This page intentionally left blank. 


\subsection{TANK SAMPLING OVERVIEW}

This section describes the November 1995 sampling and analysis event for tank 241-AN-106. Grab samples were taken to satisfy the requirements of the Tank Safety Screening Data Quality Objective (Dukelow et al. 1995). The sampling and analyses were performed in accordance with the Tank 241-AN-106 Grab Sampling and Analysis Plan (Conner 1995). For further discussions of the sampling and analysis procedures, refer to the Tank Characterization Reference Guide (DeLorenzo et al. 1994).

\subsection{DESCRIPTION OF SAMPLING EVENT}

Four grab samples (6AN-95-1, 6AN-95-2, 6AN-95-3, and 6AN-95-4) were collected from riser 22A of tank 241-AN-106 on November 21, 1995. An additional four grab samples (6AN-95-5, 6AN-95-6, 6AN-95-7, and 6AN-95-8) were collected from riser 21A on November 22, 1995. These samples were collected at four depths from each riser (see Table 3-3). The supernate sample depths were chosen not at random but to sample the surface and intermediate volumes of supernate at approximately equal intervals.

In an attempt to obtain sludge material, samples 6AN-95-4 and 6AN-95-8 were collected at $13 \mathrm{~cm}$ (5 in.) from the tank bottom; however, less than about one gram of solids was obtained.

The eight grab samples were received at the Westinghouse Hanford Company 222-S Laboratory on November 22, 1995. The deionized water field blank was generated using riser 22A on December 29, 1995 (Esch 1996a).

Prior to grab sampling, the tank headspace was sampled to determine the flammable gas concentration as required by the safety screening DQO. The flammable gas samples were taken $6.1 \mathrm{~m}(20 \mathrm{ft})$ below the top of riser 22A. Table 3-1 summarizes the sampling and analysis requirements of the safety screening $\mathrm{DQO}$.

\subsection{SAMPLE HANDLING}

Eight grab samples and one field blank were taken from tank 241-AN-106. Visual observations at the 222-S Laboratory indicated there was less than $1 \mathrm{gram}$ of solids in these samples. Because this sample amount was insufficient for analysis, the tank coordinator instructed the laboratory to analyze only the supernate in the samples. The eight samples were described as clear and yellow or gray-yellow in color. No organic layer was observed, 
Table 3-1. Integrated Data Quality Objective Requirements for Tank 241-AN-106.

\begin{tabular}{|l|l|l|l|}
\hline Grab sampling & Safety screening & $\begin{array}{l}\text { Vertical profile } \\
\text { from two } \\
\text { widely spaced } \\
\text { risers }\end{array}$ & $\begin{array}{l}\text { - Moisture content (TGA) } \\
\text { - Energetics (DSC) } \\
\end{array}$ \\
& & $\begin{array}{l}\text { - Density } \\
\text { - Total alpha activity } \\
\text { - Concentration of flammable } \\
\text { gas in headspace or } \\
\text { flammability of gas in } \\
\text { headspace }\end{array}$ \\
\hline
\end{tabular}

and only four samples contained trace amounts of solids. Table 3-2 shows the sampling location (riser number), customer identification (ID) number, laboratory sample ID number, and the contact dose rate from chain-of-custody reports. Table 3-3 shows the customer ID, sample elevation, and sample appearance.

From each grab sample and the field blank, one 20-mL unfiltered subsample was recovered for safety screening analyses, and a $60-\mathrm{mL}$ unfiltered subsample was archived. A 40-mL subsample of each grab sample will be held for future analysis by the Process Chemistry and Statistics Group at the 222-S Laboratory.

\subsection{SAMPLE ANALYSIS}

The analyses performed on the grab samples supported the safety screening DQO as specified in the Tank 241-AN-106 Grab Sampling and Analysis Plan (Conner 1995). The analyses included energetics by DSC, moisture by TGA, fissile content by total alpha activity analysis, and bulk density. The tank headspace samples were analyzed using a combustible gas meter. A TOC analysis was performed in an attempt to verify the type of waste in tank 241-AN-106.

Sections 4.0 and 5.0 describe the results of the tank safety screening analyses. They were originally published in the 45-Day Safery Screening Results and Final Report for Tank 241-AN-106, Grab Samples 6AN-95-1 through 6AN-95-9 (Esch 1996a).

The appropriate quality control checks were applied to each analysis. Section 5.1.2 describes the quality control procedures and data. 
Table 3-2. Sample Identification Numbers, Sample Volumes, and Dose Rates. ${ }^{1}$

\begin{tabular}{|c|c|c|c|c|}
\hline (1) & 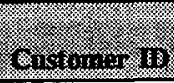 & . & wingen & (9) \\
\hline \multirow[t]{4}{*}{$22 \mathrm{~A}$} & $6 \mathrm{AN}-95-1$ & \$96T000131 & 125 & 250 \\
\hline & $6 \mathrm{AN}-95-2$ & S96T000132 & 125 & 200 \\
\hline & 6AN-95-3 & S96T000133 & 125 & 600 \\
\hline & $6 \mathrm{AN}-95-4$ & S96T000135 & 125 & 1,000 \\
\hline \multirow[t]{4}{*}{$21 \mathrm{~A}$} & $6 \mathrm{AN}-95-5$ & \$96T000149 & 125 & 300 \\
\hline & 6AN-95-6 & S96T000150 & 125 & 250 \\
\hline & $6 \mathrm{AN}-95-7$ & S96T000151 & 125 & 500 \\
\hline & $6 A N-95-8$ & S96T000152 & 125 & 800 \\
\hline $22 \mathrm{~A}$ & $6 \mathrm{AN}-95-9^{2}$ & S96T000134 & 125 & $<0.5$ \\
\hline
\end{tabular}

Notes:

'Esch (1996a)

'Field blank

Table 3-3. Tank 241-AN-106 Sample Descriptions. ${ }^{1}$

\begin{tabular}{|c|c|c|c|c|c|c|}
\hline \multirow{3}{*}{$\frac{6_{10}+10}{6 A N-95-1}$} & \multirow{2}{*}{\multicolumn{2}{|c|}{ 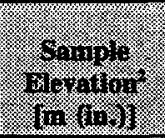 }} & \multicolumn{3}{|c|}{$4 \sin 14=$} & \\
\hline & & & \multirow{2}{*}{$\frac{\text { Yellow }}{\text { Yow }}$} & \multirow{2}{*}{$\frac{28+18}{\text { Clear }}$} & \multirow{2}{*}{$\frac{\frac{6}{3+1}+1}{\text { None }}$} & \multirow{2}{*}{2010} \\
\hline & 3.81 & $(150)$ & & & & \\
\hline $6 \mathrm{AN}-95-2$ & 2.03 & $(80)$ & Yellow & Clear & None & None \\
\hline $6 \mathrm{AN}-95-3$ & 0.51 & (20) & Yellow & Clear & None & None \\
\hline $6 \mathrm{AN}-95-4$ & 0.13 & (5) & Grey/yellow & Clear & None & Trace, gray/brown \\
\hline $6 \mathrm{AN}-95-5$ & 3.81 & $(150)$ & Yellow & Clear & None & Trace, gray/brown \\
\hline $6 \mathrm{AN}-95-6$ & 2.03 & (80) & Yellow & Clear & None & Trace, orange/brown \\
\hline 6AN-95-7 & 0.51 & (20) & Yellow & Clear & None & None \\
\hline $6 \mathrm{AN}-95-8$ & 0.13 & (5) & Gray/yellow & Clear & None & Trace, gray/brown \\
\hline 6 AN $-95-9^{3}$ & 10.97 & (432) & Colorless & Clear & None & None \\
\hline
\end{tabular}

Notes:

'Esch (1996a)

'Sample elevation is measured from the tank bottom to the mouth of the sample bottle.

${ }^{3}$ The field blank was taken in tank headspace through riser $22 \mathrm{~A}$. 
All reported analyses, except bulk density, were performed in duplicate and on direct samples in accordance with approved laboratory procedures. Table 3-4 lists the analytical procedures by title and number. No deviations or modifications were noted by the laboratory.

Table 3-4. Analytical Procedures. ${ }^{1}$

\begin{tabular}{|l|l|c|c|}
\hline Energetics by DSC & $\begin{array}{l}\text { Mettler } \\
\text { Perkin-Elmer }\end{array}$ & $n / a$ & $\begin{array}{l}\text { LA-514-113 Rev. C-1 } \\
\text { LA-514-114 Rev. C-1 }\end{array}$ \\
\hline Percent water by TGA & $\begin{array}{l}\text { Mettler } \\
\text { Perkin-Elmer }\end{array}$ & $\mathrm{n} / \mathrm{a}$ & $\begin{array}{l}\text { LA-560-112 Rev. B-1 } \\
\text { LA-514-114 Rev. C-1 }\end{array}$ \\
\hline Total alpha activity & $\begin{array}{l}\text { Alpha proportional } \\
\text { counter }\end{array}$ & $\mathrm{n} / \mathrm{a}$ & LA-508-101 Rev. D-2 \\
\hline Bulk density & n/a & $\mathrm{n} / \mathrm{a}$ & LO-160-103 Rev. B-0 \\
\hline TOC & $\begin{array}{l}\text { Furnace oxidation with } \\
\text { coulometric detector }\end{array}$ & $\mathrm{n} / \mathrm{a}$ & LA-344-105 Rev. C-0 \\
\hline
\end{tabular}

Notes:

$\mathbf{n} / \mathbf{a}=$ not applicable

Mettler ${ }^{\mathrm{TM}}$ is a registered trademark of Mettler Electronics, Anaheim, California.

Perkin-Elmer ${ }^{\text {TM }}$ is a registered trademark of Perkins Research \& Manufacturing Co. Inc., Canoga Park, California.

'Esch (1996a)

\subsection{DESCRIPTION OF APRIL 1995 GRAB SAMPLING EVENT}

Tank 241-AN-106 received a major waste transfer from tank 241-AW-106 in September 1994 , increasing its total waste volume from about $87 \mathrm{~kL}$ (23 kgal) to $1,600 \mathrm{~kL}$ (423 kgal). Consequently, the analytical results from sampling events of tank 241-AN-106 prior to September 1994 would not represent the tank contents when the tank was sampled in November 1995.

On April 4 and 5, 1995, the tank supernate was grab sampled through riser 22A (WHC 1995a). The samples were taken for a waste compatibility study with 
tank 241-AY-101 waste. The April 4 sample, numbered 6AN-95-1, was acquired at a depth of $13.5 \mathrm{~m}$ (44.3 ft) which corresponds to a sample elevation of $3.58 \mathrm{~m}$ (11.8 ft) from the tank bottom. The April 5 sample, numbered 6AN-95-2, was taken at a depth of $16.5 \mathrm{~m}$ $(54.0 \mathrm{ft})$ which corresponds to a sample elevation of $0.61 \mathrm{~m}(2.0 \mathrm{ft})$ from the tank bottom. Although these sample numbers are identical to those of the first two samples drawn from riser 22A during the November 1995 sampling event, these are indeed separate samples.

The samples were received at the 222-S Laboratory on the same day they were sampled. Equal volumes of the two samples were mixed to form a composite supernate sample (Beck 1995). The composite was combined with waste samples from tank 241-AY-101 and used to study the following: (1) mixing/compatibility with tank 241-AY-101 waste, (2) boildown characteristics, and (3) density characteristics of the combined waste (Beck 1995). The samples from tank 241-AN-106 were not analyzed independently before being mixed with tank 241-AY-101 waste samples. Section 4.7 summarizes the results from this study.

The waste in tank 241-AN-106 was derived from waste in tank 241-AW-106 and from the 242-A Evaporator 94-1 Campaign. Le (1994) and DiCenso et al. (1994) report the composition of the waste in tank 241-AW-106 prior to the addition of the campaign 94-1 product. The final product from campaign 94-1 was characterized as samples V97, V108, and V111 (Miller 1996). Appendix A summarizes the analytical results from these two waste sources and, using certain assumptions, attempts to predict the composition of the current contents of tank 241-AN-106 based on these sources. The information in Appendix $A$ is provided as background information only; no decisions regarding the waste in tank 241-AN-106 should be based on the data in Appendix A. Appendix A contains estimates of total inorganic carbon (TIC), TOC, hydroxide, cyanide, ion-chromatography anions, metals, radionuclides, and selected organic compounds in the tank 241-AN-106 waste. Section 5.2 compares the results from Appendix A with the results of the November 1995 samples. 
WHC-SD-WM-ER-569 Rev. 0

This page intentionally left blank. 


\subsection{ANALYTICAL RESULTS}

\subsection{OVERVIEW}

Section 4.0 provides the analytical results of the grab samples taken from tank 241-AN-106. The sampling and analysis were performed according to the sampling and analysis plan (Conner 1995), which includes requirements for the safety screening DQO. This section contains a summary of the requested analytes and analytical results and a discussion of each analysis. Table 4-1 shows the table locations for each set of analytical results.

Table 4-1. Analytical Data Tables.

\begin{tabular}{|l|c|}
\hline & Table 4-2 \\
\hline Total alpha activity & Table 4-3 \\
\hline Bulk density & Table 4-4 \\
\hline Thermogravimetric analysis & Table 4-5 \\
\hline Differential scanning calorimetry & Table 4-6 \\
\hline TOC &
\end{tabular}

Overall tank means were calculated for total alpha activity, bulk density, weight percent water, and TOC. To derive an overall mean, the mean for each grab sample was calculated by averaging the result and duplicate values, then the mean for each riser was calculated by averaging the four grab sample means within a riser. Finally, the overall tank mean was calculated by averaging the two riser means.

The overall mean for a given analyte is considered a detected value only if 50 percent or more of the individual sample/duplicate results are detected. Similarly, the relative standard deviation (RSD) of the mean was calculated only for the three sample characteristics (density, weight percent water, and TOC) that had 50 percent or more of the individual results detected. For those results that were less than the detection limit, the value of the detection limit was used in the calculation of the mean concentrations and standard deviations. The means and standard deviations so calculated are biased estimates of the true population means and standard deviations. The magnitude of the bias is unknown.

The RSD (mean) is defined as the standard deviation of the mean divided by the overall tank mean, times 100 . It was computed using standard analysis of variance (ANOVA) 
statistical techniques. Appendix B has a detailed explanation of the statistical analysis of the tank 241-AN-106 analytical results.

The four quality control parameters assessed on the tank 241-AN-106 samples were standard recoveries, spike recoveries, duplicate analyses, and blanks. Section 5.1.2 summarizes the results. Sample and duplicate pairs with quality control results that deviate from their specified limits are footnoted in the data summary tables.

\subsection{TOTAL ALPHA}

Total alpha analyses were performed by direct analysis according to procedure LA-508-101, Rev. D-2. All sample aliquots were dried on a counting planchet and measured for alpha activity using an alpha proportional counter.

The highest detected total alpha result of any sample was $0.00173 \mu \mathrm{Ci} / \mathrm{mL}$, and the overall tank mean was $<0.00684 \mu \mathrm{Ci} / \mathrm{mL}$. Table 4-2 shows the total alpha activity data for tank 241-AN-106.

Table 4-2 shows a number of less-than values that are larger than some of the detected values. This phenomenon is rooted in how less-than values for counting data are calculated (Jones 1995), and it stems from the following two factors.

- The background count rate is determined once each eight-hour shift. If a sample has a count rate not statistically significantly different from the background count rate, the sample is assigned a less-than value. The less-than value is proportional to the square root of the sum of the background and sample count rates; the higher these count rates, the higher the non-detect value.

- The less-than value is inversely proportional to the sample mass; the smaller the mass of a sample that generates a non-detect value, the larger the less-than value. Therefore, a small sample that generates a non-detect value can generate a less-than value that is greater than a larger sample that generates a small, but statistically significant, detected value.

\subsection{BULK DENSITY}

The bulk density of each sample was determined using procedure LO-160-103, Rev. B-0. Table 4-3 shows sample numbers, risers, density results, and mean. Although the tank 241-AN-106 sampling and analysis plan (Conner 1995) did not call out duplicate determinations for density, the laboratory did perform duplicate density determinations on samples S96T000140 and \$96T000156. 
Table 4-2. Total Alpha Activity Results for Tank 241-AN-106. ${ }^{1}$

\begin{tabular}{|c|c|c|c|c|c|c|}
\hline Siminge & 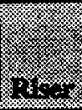 & 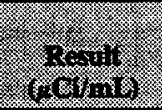 & 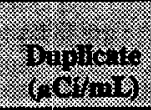 & 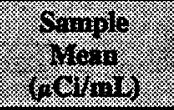 & 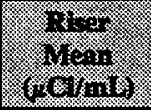 & 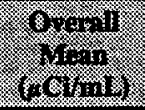 \\
\hline 136 & \multirow[t]{4}{*}{$22 \mathrm{~A}$} & 0.00116 & $<0.00141$ & $<0.00128^{3}$ & \multirow[t]{4}{*}{$<0.00231$} & \multirow[t]{8}{*}{$<0.00684$} \\
\hline 137 & & $<0.000786$ & 0.00116 & $<0.000973^{3}$ & & \\
\hline 138 & & 0.00173 & $<0.00141$ & $<0.00157^{3}$ & & \\
\hline 140 & & $<0.00503$ & $<0.00582$ & $<0.00542$ & & \\
\hline 153 & \multirow[t]{4}{*}{$21 \mathrm{~A}$} & $<0.00253$ & $<0.00257$ & $<0.00255$ & \multirow[t]{4}{*}{$<0.01136$} & \\
\hline 154 & & $<0.00325$ & $<0.00253$ & $<0.00289$ & & \\
\hline 155 & & $<0.0633$ & $<0.00513$ & $<0.0342$ & & \\
\hline 156 & & $<0.00495$ & $<0.00662$ & $<0.00578$ & & \\
\hline
\end{tabular}

Notes:

$\mathbf{n} / \mathbf{a}=$ not applicable

'Esch (1996a)

${ }^{2}$ All sample numbers begin with S96T000.

${ }^{3}$ The standard recovery was below the 80 to 110 percent recovery mange defined in DOE (1995).

Table 4-3. Density Results for Tank 241-AN-106.'

\begin{tabular}{|c|c|c|c|c|c|c|}
\hline inging & $\begin{array}{l}.8 \\
3 \\
3\end{array}$ & 紋 & $(1 / 1)$ & 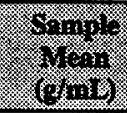 & 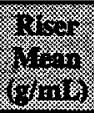 & 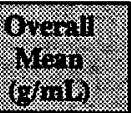 \\
\hline 136 & \multirow[t]{4}{*}{$22 \mathrm{~A}$} & 1.18 & $\mathrm{n} / \mathrm{a}$ & 1.18 & \multirow[t]{4}{*}{1.19} & \multirow[t]{8}{*}{1.19} \\
\hline 137 & & 1.17 & $\mathrm{n} / \mathrm{a}$ & 1.17 & & \\
\hline 138 & & 1.18 & $\mathrm{n} / \mathrm{a}$ & 1.18 & & \\
\hline 140 & & 1.21 & 1.22 & 1.22 & & \\
\hline 153 & \multirow[t]{4}{*}{$21 \mathrm{~A}$} & 1.16 & $\mathrm{n} / \mathrm{a}$ & 1.16 & \multirow[t]{4}{*}{1.18} & \\
\hline 154 & & 1.18 & $\mathrm{n} / \mathrm{a}$ & 1.18 & & \\
\hline 155 & & 1.19 & $\mathrm{n} / \mathrm{a}$ & 1.19 & & \\
\hline 156 & & 1.18 & 1.20 & 1.19 & & \\
\hline \multicolumn{7}{|c|}{ Percent relative standard deviation of the overall mean $=0.63 \%$} \\
\hline
\end{tabular}

Notes:

$\mathrm{n} / \mathbf{a}=$ not applicable

'Esch (1996a)

${ }^{2}$ All sample numbers begin with $\$ 96 \mathrm{~T} 000$. 


\subsection{THERMAL ANALYSES}

As requested by the safety screening DQO, TGA and DSC were performed on the samples (Dukelow et al. 1995). The following sections discuss these results.

\subsubsection{Thermogravimetric Analysis}

In TGA, the mass of a sample is measured while its temperature is increased at a constant rate. A gas, such as nitrogen or air, is passed over the sample during heating to remove any released gases. A decrease in the weight of a sample represents a loss of gaseous matter from the sample through evaporation or through a reaction that forms gas phase products.

Weight percent water by TGA was performed under a nitrogen purge using procedure LA-560-112, Rev. B-1, for a Mettler ${ }^{\text {TM }}$ instrument and procedure LA-514-114, Rev. C-1, for a Perkin-Elmer ${ }^{\mathrm{TM}}$ instrument. Table 4-4 shows the sample results. The overall average for the tank was 76.6 weight percent water with an overall RSD of 1.10 percent.

\subsubsection{Differential Scanning Calorimetry}

In DSC analysis, heat absorbed or emitted by a substance is measured while its temperature is increased at a constant rate. While the substance is being heated, a gas, such as nitrogen, is passed over the waste material to remove any gases being released. The onset temperature for an endothermic (characterized by or causing the absorption of heat) or exothermic (characterized by or causing the release of heat) event is determined graphically.

Analyses by DSC were performed under a nitrogen atmosphere using procedure LA-514-113, Rev. C-1, for a Mettler ${ }^{\mathrm{TM}}$ Model 20 differential scanning calorimeter, and procedure LA-514-114, Rev. C-1, for a Perkin-Elmer ${ }^{\mathrm{TM}}$ instrument. All results were endothermic.

Table 4-5 shows DSC results. Only one transition was observed. The sample weight, temperature at maximum enthalpy change, and the magnitude of the enthalpy change are provided for the transition. The transition represents the endothermic reaction associated with the evaporation of free and interstitial water.

\subsection{TANK HEADSPACE FLAMMABILITY}

Vapor samples were taken from the tank 241-AN-106 headspace prior to grab sampling to satisfy the safety screening DQO. The samples were analyzed using a combustible gas meter, and the flammable vapor content was determined to be 0 percent of the LFL, indicating no flammability concerns. Ir addition, the concentrations of ammonia gas ( 0 parts per million [ppm]) and TOC vapor (0 ppm) were measured (Esch 1996a). 
Table 4-4. Thermogravimetric Analysis Results for Tank 241-AN-106.'

\begin{tabular}{|c|c|c|c|c|c|c|c|}
\hline 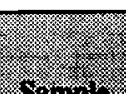 & $\sqrt{1}$ & $\frac{1}{10.010}$ & 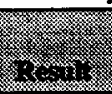 & 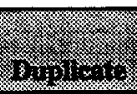 & (2) & 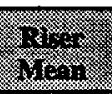 & $4 \%$ \\
\hline (1) & 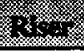 & ( & 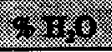 & 20 & 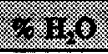 & $4 \times 8$ & 8 \\
\hline $136^{4}$ & \multirow[t]{4}{*}{$22 \mathrm{~A}$} & $\begin{array}{c}35 \text { to } 127 \\
\text { (35 to } 137)\end{array}$ & 78.71 & 78.35 & 78.53 & \multirow[t]{4}{*}{76.5} & \multirow[t]{8}{*}{76.6} \\
\hline $137^{4}$ & & $\begin{array}{c}35 \text { to } 143 \\
\text { (35 to } 119)\end{array}$ & 76.86 & 77.26 & 77.06 & & \\
\hline $138^{4}$ & & $\begin{array}{c}32 \text { to } 204 \\
\text { (26 to } 207)\end{array}$ & 76.56 & 75.48 & 76.02 & & \\
\hline $140^{4}$ & & $\begin{array}{c}35 \text { to } 135 \\
\text { (35 to } 130)\end{array}$ & 75.32 & 73.71 & 74.52 & & \\
\hline $153^{4}$ & \multirow[t]{4}{*}{$21 \mathrm{~A}$} & $\begin{array}{c}35 \text { to } 105 \\
\text { (35 to } 115)\end{array}$ & 77.76 & 77.92 & 77.84 & \multirow[t]{4}{*}{76.7} & \\
\hline $154^{5}$ & & $\begin{array}{c}27 \text { to } 497 \\
\text { (22 to } 497)\end{array}$ & 79.37 & 77.14 & 78.26 & & \\
\hline $155^{5}$ & & $\begin{array}{c}24 \text { to } 497 \\
\text { (31 to } 497)\end{array}$ & 75.92 & 76.21 & 76.06 & & \\
\hline $156^{4}$ & & $\begin{array}{l}35 \text { to } 115 \\
\text { (35 to } 115)\end{array}$ & 74.23 & 74.64 & 74.44 & & \\
\hline \multicolumn{8}{|c|}{ Percent relative standard deviation of the overall mean $=1.10 \%$} \\
\hline
\end{tabular}

Notes:

Temp. = temperature

'Esch (1996a)

${ }^{2}$ All sample numbers begin with S967000.

${ }^{3}$ The range in parentheses is for the duplicate.

${ }^{4}$ Percent water by thermogravimetric analysis using a Mettler ${ }^{\mathrm{TM}}$ instrument.

${ }^{5}$ Percent water by thermogravimetric analysis using a Perkin-Elmer ${ }^{T M}$ instrument. 
Table 4-5. Differential Scanning Calorimetry Results for Tank 241-AN-106. ${ }^{1}$

\begin{tabular}{|c|c|c|c|c|c|}
\hline 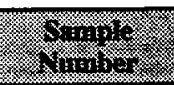 & 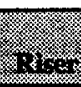 & 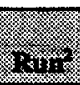 & 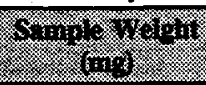 & $\frac{1}{46}$ & 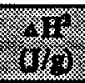 \\
\hline \multirow[t]{2}{*}{ S96T0001364 } & \multirow[t]{8}{*}{$22 \mathrm{~A}$} & 1 & 11.33 & 113.5 & 1859 \\
\hline & & 2 & 12.03 & 114.4 & 1956 \\
\hline \multirow[t]{2}{*}{$\$ 96 \mathrm{~T} 000137^{4}$} & & 1 & 12.49 & 113.2 & 1931 \\
\hline & & 2 & 12.03 & 113.6 & 1807 \\
\hline \multirow[t]{2}{*}{ S96T000138 } & & 1 & 23.77 & 113.8 & 1415 \\
\hline & & 2 & 23.13 & 131.9 & 1091 \\
\hline \multirow[t]{2}{*}{ S96T000140 } & & 1 & 24.96 & 119.1 & 1587 \\
\hline & & 2 & 26.03 & 116.5 & 1719 \\
\hline \multirow[t]{2}{*}{ S96T0001534 } & \multirow[t]{8}{*}{$21 \mathrm{~A}$} & 1 & 12.81 & 114.2 & 1865 \\
\hline & & 2 & 14.68 & 115.6 & 1755 \\
\hline \multirow[t]{2}{*}{ S96T0001544 } & & 1 & 18.54 & 116.4 & 1734 \\
\hline & & 2 & 13.88 & 110.3 & 1771 \\
\hline \multirow[t]{2}{*}{ S96T0001554 } & & 1 & 13.51 & 115.2 & 1931 \\
\hline & & 2 & 12.78 & 115.5 & 1757 \\
\hline \multirow[t]{2}{*}{$\$ 96 \mathrm{~T} 000156^{4}$} & & 1 & 12.17 & 104.8 & 1637 \\
\hline & & 2 & 14.36 & 116.8 & 1722 \\
\hline
\end{tabular}

Notes:

'Esch (1996a)

${ }^{2} 1$ = sample result, 2 = duplicate result

${ }^{3} \Delta \mathrm{H}$ equals a change in enthalpy.

'DSC performed using a Perkin-Elmer ${ }^{\mathrm{TM}}$ instrument.

${ }^{5}$ DSC performed using a Mettler ${ }^{\text {TM }}$ instrument.

\subsection{TOTAL ORGANIC CARBON}

TOC analyses were performed in an attempt to verify the waste type in tank 241-AN-106. Because the TOC analyses were not performed in support of tank safety issues, TOC was determined for only two grab samples, 6AN-95-1 (S96T000131) (sampled through riser 22A just below the waste surface) and 6AN-95-8 (S96T000152) (sampled through riser 21A near the tank bottom). Procedure LA-344-105, Rev. C-0, was used for the determination. Table 4-6 shows the TOC results by sample number, riser, and mean. 
Table 4-6. Total Organic Carbon Results for Tank 241-AN-106. ${ }^{1}$

\begin{tabular}{|c|c|c|c|c|c|c|}
\hline \%imp & 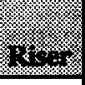 & (8) & 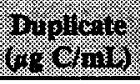 & 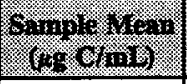 & 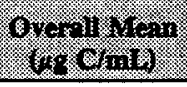 & (n) $(0,121)$ \\
\hline 131 & $22 \mathrm{~A}$ & 5,370 & 4,760 & 5,070 & \multirow[t]{2}{*}{4,390} & \multirow[t]{2}{*}{15.3} \\
\hline 152 & $21 \mathrm{~A}$ & 3,740 & 3,700 & 3,720 & & \\
\hline
\end{tabular}

Notes:

\footnotetext{
${ }^{1}$ Esch (1996a)

${ }^{2}$ All sample numbers begin with S96T)00.

${ }^{3}$ Percent relative standard deviation of the overall mean
}

\subsection{APRIL 1995 GRAB SAMPLE RESULTS}

Tank 241-AN-106 supernate was grab sampled in April 1995 to support a waste compatibility and boildown study with tank 241-AY-101 supernate (Beck 1995). In the Beck (1995) study, supernate samples from tanks 241-AN-106 and 241-AY-101 were combined and used to study the following: (1) mixing/compatibility with 241-AY-101 supernate, (2) boildown characteristics, and (3) density characteristics of the combined waste. The boildown and density characteristics of the tank 241-AY-101 supernate alone were also determined but are not discussed in this document.

In the mixing/compatibility study, supernate from the two tanks was combined to yield volume percents (defined as a percent of tank 241-AN-106 waste in the total waste volume) of $25,30,35,44$, and 50 percent. Free hydroxide was determined for each combination. Table 4-7 shows the results of these determinations.

Table 4-7. Free Hydroxide Concentration in Mixtures of Supernate from Tanks 241-AN-106 and 241-AY-101. ${ }^{1}$

\begin{tabular}{|c|c|c|c|c|c|c|}
\hline 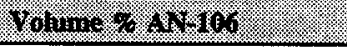 & 288 & $80 \%$ & $35 \%$ & 198. & $187 \%$ & $50 \%$ \\
\hline $\mathrm{OH}^{-}$Concentration $(M)$ & $<0.01$ & 0.046 & 0.088 & 0.185 & 0.189 & 0.197 \\
\hline $\mathrm{OH}^{-}$Concentration $(\mu \mathrm{g} / \mathrm{mL})$ & $<170$ & 780 & 1,500 & 3,150 & 3,210 & 3,350 \\
\hline
\end{tabular}

Notes:

$$
\begin{aligned}
& M=\text { moles } / \mathrm{L} \text { (molarity) } \\
& \text { 'Beck (1995) }
\end{aligned}
$$


A linear extrapolation of the hydroxide content to 100 percent tank 241-AN-106 supernate yields a concentration of $11,200 \mu \mathrm{g} / \mathrm{mL}$ hydroxide. This value is consistent with the calculated value $15,800 \mu \mathrm{g} / \mathrm{mL}$ hydroxide from Appendix A.

No major color changes, heat generation, foaming, precipitations, or obvious density differences were observed after mixing 25:75 and 30:70 ratios of tank

241-AN-106:241-AY-101 supernates. 'The mixed supernates were light yellow in color. Differential scanning calorimetry was performed on aliquots of the mixtures. No exotherms were observed in scans conducted to $500^{\circ} \mathrm{C}$. The only endotherm observed in each scan was attributed to water loss.

A boildown study of a 30:70 mixture of tank 241-AN-106:241-AY-101 supernates was performed. Three nominal pressures were used during the course of the boildown study: $10,7.3$, and $4.3 \mathrm{kPa}(75,55$, and 32 torr). During volume reduction, the still pot temperatures ranged from 48.4 to $54.8^{\circ} \mathrm{C}$ at $10 \mathrm{kPa}(75 \mathrm{torr})$, from 43.2 to $48.8^{\circ} \mathrm{C}$ at $7.3 \mathrm{kPa}$ ( $55 \mathrm{torr})$, and from 37.0 to $41.2{ }^{\circ} \mathrm{C}$ at $4.3 \mathrm{kPa}$ (32 torr). The boildown was conducted to an endpoint equivalent to a 76 percent waste volume reduction (WVR). The initial supernate mixture was described as cloudy at $48^{\circ} \mathrm{C}$; no cloudiness was reported at room temperature. During the boildown, some initial solution foaming was noted at 10 percent WVR; thereafter the solution boiled and formed large, non-persistent bubbles with no foaming or bumping. The solution continued to darken during boildown. At 39 percent WVR, particulates became visible in the solution, and by 50 percent WVR, a large amount of solids had precipitated. The final product at 76 percent WVR was a thick, orange-yellow, pourable sludge containing visible granular material and some clumps of stiff, non-pourable sludge.

Solution/slurry densities were determined for the mixture boildown at various percent WVRs. The results were $1.12 \mathrm{~g} / \mathrm{mL}$ ( 0 percent WVR), $1.20 \mathrm{~g} / \mathrm{mL}$ (50 percent WVR), $1.35 \mathrm{~g} / \mathrm{mL}$ (70 percent WVR), and $1.55 \mathrm{~g} / \mathrm{mL}$ ( 76 percent WVR). Densities were measured at sample temperatures between 25 and $30^{\circ} \mathrm{C}$. 


\subsection{INTERPRETATION OF CHARACTERIZATION RESULTS}

This section discusses the overall quality and consistency of the current sampling results for tank 241-AN-106 and assesses these results against program requirements.

\subsection{ASSESSMENT OF SAMPLING AND ANALYTICAL RESULTS}

Sampling and analysis factors that may impact data interpretation are summarized. These factors are used to assess the overall data quality and consistency and to identify any limitations in data use. Given the limited scope of the analyses, most of the usual consistency checks were not possible.

\subsubsection{Field Observations}

A vertical profile of the tank supernate was taken from two widely spaced risers as required by the safety screening DQO (Dukelow et al. 1995). A horizontal and vertical comparison of the analytical results between the two grab samples was possible, thereby providing an estimate of the distribution of waste constituents in the supernate (see Section 5.3).

Two samples were taken from a sample elevation of approximately $13 \mathrm{~cm}$ (5 in.) in an attempt to collect a sludge sample (Esch 1996a). The sludge portions were not analyzed because the samples contained too little solid material for analysis (< one gram). Failure to obtain any sludge solids may indicate one of the following: (1) there was no sludge to sample, or (2) the sludge layer was too thin for the sampler to adequately penetrate and sample. Hanlon (1996b) indicates that tank 241-AN-106 contains $64 \mathrm{~kL}$ (17 kgal) of sludge layer as determined by sludge weight measurements. This converts to a sludge depth of $16 \mathrm{~cm}$ (6 in.).

To understand why the grab sampler may not have been able to sample a 13-to-16-cm thick sludge layer, it is helpful to understand the grab sampler's construction. The grab sampler used in the November 1995 sampling event was constructed of a stainless-steel bracket that held a $125 \mathrm{~mL}$ sample bottle (WHC 1995d). A torpedo-shaped, 17-cm (6.75-in.) high, stainless-steel sludge weight was attached to the bottom of the bracket. The entire distance from the bottom of the sludge weight to the mouth of the sample bottle was approximately $25 \mathrm{~cm}(9.8 \mathrm{in}$.). To sample a siudge layer approximately $16 \mathrm{~cm}$ thick, the sampler would have to be tipped on its side. With no in-tank video feedback to guide such a sludge sampling operation with the grab sampler, it is not surprising that very few solids were collected from the sludge layer.

The field blank was acquired in the tank headspace through riser $22 \mathrm{~A}$ on November 29 , one week after the last grab samples were obtained from the tank. Although the field blank 
showed no contamination from the sampling process, the blank's value for indicating contamination during the sampling process is reduced because it was not acquired at the same time as the other grab samples.

\subsubsection{Quality Control Assessment}

The usual quality control assessment includes an evaluation of the appropriate standard recoveries, spike recoveries, duplicate analyses, and blanks performed in conjunction with the chemical analyses. All pertinent quality control tests were conducted on the 1995 grab samples and reported in Esch (1996a). The Hanford Analytical Services Quality Assurance Plan (DOE 1995) establishes the specific accuracy and precision criteria for the quality control checks (Conner 1995).

Of the four standard recoveries conducted with the total alpha activity analyses, one was slightly below the target level of 80 to 110 percent recovery (79.22 percent recovery). This standard was within the statistical process control limits for the method, and no reruns were requested because the sample results were considered acceptable. Also, the analytical results were far below the safety screening action limit, and any deviation was not substantial enough to affect the criticality evaluation. All spike recoveries were within the specified criterion. The precision (estimated by the relative percent difference, which is defined as the absolute value of the difference between the primary and duplicate samples, divided by their mean, times one hundred) between all sample pairs for all analytes were within the limits. Finally, no sample exceeded the criterion for preparation blanks; therefore, contamination was not a problem for any analysis.

In summary, all but one quality control result were within the boundaries specified in the sampling and analysis plan, and this exception (the low total alpha standard recovery noted in the previous paragraph) did not substantially impact data validity or use.

\subsubsection{Data Consistency Checks}

Comparing different analytical methods is useful in assessing data consistency and quality. Examples of data consistency checks inciude the calculation of mass and charge balances, the comparison of sulfur and phosphorus concentrations (as measured by inductively coupled plasma spectroscopy) to sulfate and phosphate results (as determined by ion chromatography), and the comparison of total alpha and total beta activities to the sums of their individual emitters. Because of the lack of radionuclide data (other than total alpha activity) and chemical data, no data consistency checks of these types were possible.

Although standard data consistency checks were not possible, some results from the November 1995 grab samples, the April 1995 grab samples, and the calculated composition from Appendix A may be examined to compare peripheral data at a high level to see if the 
data is consistent. The comparison of these results must be tempered with the understanding that (1) results other than those from November 1995 are from a mixture of supemate wastes from tanks 241-AN-106 and 241-AY-101 (Beck 1995) or are estimated from mathematical combinations from several sources (see Appendix A), and (2) the statistical error limits of the Beck (1995) and Appendix A data are unknown. Therefore, these checks are for information only.

From Table 4-3, the overall mean density for the November 1995 supernate samples is $1.19 \mathrm{~g} / \mathrm{mL}$. The density of the V97 sample from the 242-A Evaporator 94-1 Campaign was also reported as $1.19 \mathrm{~g} / \mathrm{mL}$, but the density of the AW-106 supernate was unknown, therefore a combined density could not be determined from these two waste sources. However, the density of a 30:70 241-AN-106:241-AY-101 supernate mixture was determined to be $1.12 \mathrm{~g} / \mathrm{mL}$ (Beck 1995), and the density of $241-\mathrm{AY}-101$ supernate is $1.08 \mathrm{~g} / \mathrm{mL}$ (Esch 1996b). From these two values the dersity of tank 241-AN-106 was estimated to be $1.21 \mathrm{~g} / \mathrm{mL}$. Although the November 1995 analytical density $(1.19 \mathrm{~g} / \mathrm{ml})$ and the estimated density $(1.21 \mathrm{~g} / \mathrm{mL})$ were determined from different waste formulations, the density values appear to be consistent with each other.

For the November 1995 samples, Table 4-4 reports an overall mean of 76.6 weight percent water. Beck (1995) does not report any weight percent water values, but Table A-3 gives an upper estimate of 77.9 weight percent water from mass balance considerations. The 77.9 weight percent value is remarkably consistent with the 76.6 weight percent value.

The DSC results from Section 4.4.2 indicate a single endotherm caused by water loss was observed for the November 1995 samples. Beck (1995) reports a similar observation for DSC performed on the 30:70 241-AN-106:241-AY-101 supernate mixtures. The Beck (1995) results appear to corroborate the observation that the fuel in tank 241-AN-106 supernate is not sufficient to generate exothermic reactions.

The overall mean total alpha result from Table $4-2$ is $<0.00684 \mu \mathrm{Ci} / \mathrm{mL}$; no total alpha estimates are available from Beck (1995) or the "Combined" column of Table A-1. However, the total alpha result from the "V97" column of Table A-1 is $<0.023 \mu \mathrm{Ci} / \mathrm{mL}$. This value seems consistent with that observed for November 1995 samples. The estimated value of $<0.000519 \mu \mathrm{Ci} / \mathrm{mL}$ plutonium from the "Combined" column of Table A-1 also supports the criticality evaluation as defined by the mean total alpha value from Table 4-2.

The overall mean value for TOC from Table $4-6$ is $4,390 \mu \mathrm{g} \mathrm{C} / \mathrm{mL}$. Table A-1 reports a value of $2,090 \mu \mathrm{g} \mathrm{C} / \mathrm{mL}$ in the "Combined" column. The 95 percent confidence limits on the $4,390 \mu \mathrm{g} \mathrm{C} / \mathrm{mL}$ result are $\pm 2,890 \mu \mathrm{g} \mathrm{C} / \mathrm{mL}$ (standard deviation of the mean $=672 \mu \mathrm{g} \mathrm{C} / \mathrm{mL}, \mathrm{t}=4.30$ at the 95 percent level, two degrees of freedom). The value of $2,090 \mu \mathrm{g} \mathrm{C} / \mathrm{mL}$ is inside the confidence interval. (The uncertainty on the $2,090 \mu \mathrm{g} \mathrm{C} / \mathrm{mL}$ value is unknown; therefore, a more rigorous statistical comparison of the two values is not possible.) 
In addition to the TOC estimate shown in Table A-1, Appendix A indicates that a number of volatile and semi-volatile organic compounds were identified in the waste streams that made up the supernate waste in tank 241-AN-106, for example, acetone, butanol, 2-hexanone, tributyl phosphate, tridecane, and tetradecane. However, the concentrations of the identified organic species forms only a fraction of the TOC value. The organic components were determined using gas chromatography/mass spectrometry and purge-and-trap or methylene chloride extractions (Miller 1996). Only those organic compounds that are sufficiently volatile or are easily extracted will be detected. Because much of the organic carbon was not detected using these methods, one possible interpretation is that most of the organic carbon in the tank 241-AN-106 supernate is probably in the form of complexing agents or fragments thereof. Such forms of organic carbon are not volatile and will extract poorly from the supernate.

Finally, a comparison may be made between the hydroxide content of tank 241-AN-106 supernate from Beck (1995) and that shown in the "Combined" column of Table A-1. The supernate mixture hydroxide concentration data in Table 4-7 was linearly extrapolated to 100 percent tank 241-AN-106 supernate to yield a concentration of $11,200 \mu \mathrm{g} / \mathrm{mL}$ hydroxide. This value is consistent with the calculated value of $15,800 \mu \mathrm{g} / \mathrm{mL}$ hydroxide from Appendix A.

In summary, the November 1995 sample results and other analytical information presented in this section appear to be reasonably consistent.

\subsection{COMPARISON OF HISTORICAL WITH ANALYTICAL RESULTS}

Because of significant changes in the tank waste volume since September 1994, and because April 1995 grab samples were composited and mixed with grab samples from tank 241-AY-101, no direct comparisons between the November 1995 sample event and other sampling events were possible.

\subsection{TANK WASTE PROFHL}

During the November 1995 sampling event, grab samples were acquired at four different waste depths from two different risers for a total of eight grab samples (Conner 1995). The supernate sample depths were selected not at random but to sample the surface and intermediate volumes of supernate at approximately equally spaced intervals. In an attempt to obtain sludge material, two samples (6AN-95-4 and 6AN-95-8) were collected at $13 \mathrm{~cm}$ (5 in.) as measured from the tank bottom (see Table 3-3). Hanlon (1996a) estimated that $1,520 \mathrm{~kL}$ (401 kgal) of supernatant overlay $64 \mathrm{~kL}(17 \mathrm{kgal})$ of sludge at the time the November 1995 samples were taken. The grab sampler was not able to obtain sludge which may indicate that a consolidated sludge layer approximately $13 \mathrm{~cm}$ thick covers the tank 
bottom. Because the sampler could not adequately sample the sludge layer, the sludge layer composition could not be determined.

The visual descriptions of the samples indicated that less than one gram of solids was present in the bottom sample of each riser. The remaining six supernatant samples appeared to be the same except that the upper two samples from riser $21 \mathrm{~A}$ showed a trace of graybrown/orange-brown solids. No solids were observed in the other samples (see Section 3.2). Horizontally, the descriptions were identical except for the two samples with graybrown/orange-brown colored solids.

Random effects statistical analysis of variance (ANOVA) models were fit to the weight percent water and bulk density data from the $1995 \mathrm{grab}$ samples. The results from these models may be used to judge the vertical and horizontal variability in mean analyte concentration. The ANOVA generates a p-value that is compared to a standard significance level $(\alpha=0.05$ ). If a p-value is less than 0.05 , then the sample means are significantly different from each other. Conversely, if a p-value is greater than 0.05 , then the sample means are not significantly different frorn each other. Appendix B contains the details of the ANOVA for tank 241-AN-106 analytical data.

The results of the ANOVA indicate that neither weight percent water (p-value $=0.79$ ) nor bulk density ( $p$-value $=0.57$ ) had significant concentration differences between the two risers (horizontal variability). There was no significant difference ( $p$-value $=0.22$ ) in the mean bulk density among samples within a riser. However, there were significant differences ( $p$-value $=0.02$ ) in mean weight percent water among samples within a riser (vertical heterogeneity). In the sample mean column of Table 4-4, it appears that the water concentration is decreasing as a function of depth. This may be attributed to an increasing amount of dissolved solids in the grab samples or to a larger fraction of undissolved solids that have a lower weight percent water than the supernate. The lowest percent water results are in the grab samples that were taken directly above the sludge layer.

Table 3-2 tabulates the contact dose rates for the samples, and Section B.4 provides a statistical analysis of these data. The statistical analysis shows a statistically significant increase in sample dose rate with increasing sample depth. Such a trend implies that the concentrations of the beta/gamma-emitting radioactive constituents in the tank supernate also increase with waste depth. One explanation for the vertical trend is that radionuclides are being leached into the supernate from the sludge layer on the tank bottom; a second explanation is that the radionuclides are slowly precipitating from the supernate and onto the sludge heel.

In summary, the available evidence based on the tank transfer history, sludge level measurements, and the visual description of the samples taken near the tank bottom imply that a sludge layer resides on the tank bottom. The statistical results suggest that the supernate layer exhibits a slight vertical heterogeneity in percent water content. The tank shows a definite increase in sample dose rate and in beta/gamma-emitting radionuclides with 
sample depth. Horizontally, the supernate appears to be fairly homogeneous. Because the sludge layer could not be sampled adequately, its composition is unknown. The increase in beta/gamma-emitting radionuclides with the depth of supernate may indicate the sludge layer has a higher radionuclide concentration than the supernate layer.

\subsection{COMPARISON OF TRANSFER HISTORY WITH ANALYTICAL RESULTS}

The HTCE predictions for tank 241-AN-106 are no longer valid. The predictions were

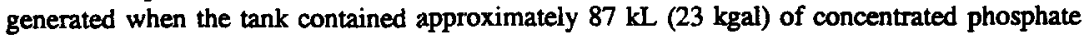
waste. Since that time, a $1,510 \mathrm{~kL}$ (400 kgal) transfer of waste from tank $241-\mathrm{AW}-106$ was received. Therefore, comparisons between the HTCE values and the analytical results were not performed.

Although the HTCE predictions are no longer valid, Appendix A does provide a very limited comparison between the analytical results and the calculated composition of tank 241-AN-106 supernate. The 241-AN-106 supernate calculated composition is based on the analytical results of tank 241-AW-106 supernate, the 242-A Evaporator 94-1 Campaign final product results, and the transfer history of the two tanks. Section 5.2 compares the tank 241-AN-106 analytical results to the calculated supernate composition in Appendix A.

\subsection{EVALUATION OF PROGRAM REQUIREMENTS}

The grab samples from tank 241-AN-106 were taken to meet the requirements of the safety screening DQO (Dukelow et al. 1995). Those requirements and a comparison between the analytical data and defined concentration limits are discussed in this section. Total organic carbon was determined for a subset of the grab samples in an attempt to verify the tank 241-AN-106 waste classification. These results are discussed in Section 5.5.2.

\subsubsection{Safety Evaluation}

The safety screening DQO requires a vertical profile of the tank waste from two widely spaced risers. This requirement was met for the tank supernate; the sludge layer could not be sampled adequately for analysis. Data criteria in the DQO are used to assess the safety of the supernate waste in tank 241-AN-106. If waste characteristics of concern are outside the criteria, further analyses may be warranted to assure tank safety. These criteria have been established for four waste characteristics: energetics, water content, total alpha activity, and flammable gas concentration.

The safety screening DQO has established a notification limit of $-480 \mathrm{~J} / \mathrm{g}$ (dry weight basis) for exothermic reactions detected during the DSC analysis. No exothermic reactions were found in any tank 241-AN-106 sample. Large amounts of moisture reduce the potential for 
propagating exothermic reactions in the waste. Reported results for all samples were above 70 weight percent water; the overall tank mean was 76.6 weight percent water with a percent relative standard deviation of the mean of 1.1 .

The criticality safety issue can be assessed from the total alpha activity data. No reported result above detection limits from the sampling event was greater than $0.00173 \mu \mathrm{Ci} / \mathrm{mL}$ total alpha activity, and the largest nondetected result was $<0.0633 \mu \mathrm{Ci} / \mathrm{mL}$. The overall mean was $<0.00684 \mu \mathrm{Ci} / \mathrm{mL}$. This was well below the notification limit of $1 \mathrm{~g} / \mathrm{L}$, or $61.5 \mu \mathrm{Ci} / \mathrm{mL}$, as specified in the safety screening DQO (see footnote 2, Table 5-1).

The DQO notification limit for flammable gas concentration is 25 percent of the LFL. The combustible gas meter used to measure flammable gas concentrations in the tank reported results as a percent of the lower explosive limit (LEL). Because the National Fire Protection Association defines the two terms identically, the terms may be used interchangeably (NFPA 1995). Combustible gas meter readings taken at the time of sampling showed the concentration of flammability gases was 0 percent of the LFL (Esch 1996a).

In summary, the November 1995 grab sampling event met all the requirements of the safety screening DQO for the tank supernate and headspace; none of the safety screening DQO criteria were exceeded. Because the sludge layer could not be adequately sampled, no assessment with regard to the tank safety DQO can be made for the sludge layer. Table 5-1 lists the safety issues, the characteristics of concern and their notification limits, and the corresponding analytical results.

Another factor in assessing the safety of the tank waste is the heat generation and waste temperature. Heat is generated in tanks from radioactive decay. The temperature data (see Section 2.4.2) indicate the tank waste high-temperature extreme was recorded when waste was added in September 1994. Because the temperature extreme occurred at the time that the thermally warm evaporator product was transferred from tank 241-AW-106 to tank 241-AN-106, the conclusion is that heat generated from the radioisotopes in the waste is being dissipated adequately.

Tank 241-AN-106 is not currently classified as a Watch List tank; however, three other tanks in the 241-AN tank farm are on the flammable gas Watch List (tanks 241-AN-103, -104, and -105). Estey and Guthrie (1996) indicate that, for all tanks exhibiting gas release events, the depth of the nonconvective (sludge) layer in the tank times the specific gravity of the supernate layer is greater than $5.8 \mathrm{~m}$ (19.2 ft). Tanks 241-AN-103, -104, and -105 exceed this value. However, no tank with a product of sludge layer thickness times supernate specific gravity less than $3.8 \mathrm{~m}$ (12.5 ft) exhibits gas release event behavior. Tank 24l-AN-106 has a sludge layer approximately $13 \mathrm{~cm}(5 \mathrm{in}$.) deep and a supernate density of $1.19 \mathrm{~g} / \mathrm{mL}$. Using the density to approximate the supernate specific gravity, this yields a sludge depth times specific gravity product of 0.15 . A value of 0.15 suggests that tank 241-AN-106 should be grouped with the non-gas release event tanks. 
Table 5-1. Safety Screening Data Quality Objective Decision Variables and Criteria.

\begin{tabular}{|c|c|c|c|}
\hline (.) & 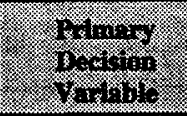 & 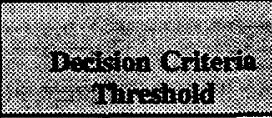 & 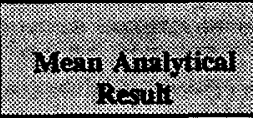 \\
\hline $\begin{array}{l}\text { Ferrocyanide/Organics } \\
\text { (Energetics) }\end{array}$ & $\begin{array}{l}\text { Total fuel } \\
\text { content }\end{array}$ & $-480 \mathrm{~J} / \mathrm{g}$ & $\begin{array}{l}\text { No exothermic } \\
\text { reactions }\end{array}$ \\
\hline Organics & Percent water & 17 weight percent & 76.6 weight percent ${ }^{1}$ \\
\hline Criticality & Total alpha & $1 \mathrm{~g} / \mathrm{L}^{2}(61.5 \mu \mathrm{Ci} / \mathrm{mL})$ & $<0.00684 \mu \mathrm{Ci} / \mathrm{mL}^{1}$ \\
\hline Flammable gas & Flammable gas & 25 percent of the LFL & $\begin{array}{l}0 \text { percent of lower } \\
\text { flammability limit }\end{array}$ \\
\hline
\end{tabular}

Notes:

${ }^{1}$ The mean value is the overall tank mean for the supernate.

${ }^{2}$ Although the actual decision criterion listed in the DQO was $1 \mathrm{~g} / \mathrm{L}$, total alpha was measured in $\mu \mathrm{Ci} / \mathrm{mL}$ rather than $\mathrm{g} / \mathrm{L}$. To convert the notification limit for total alpha into the same units as the laboratory, it was assumed that all alpha decay originated from ${ }^{20} \mathrm{Pu}$. Then, by using the specific activity of ${ }^{29} \mathrm{Pu}(0.0615 \mathrm{Ci} / \mathrm{g})$, the decision criterion may be converted to $\mu \mathrm{Ci} / \mathrm{mL}$ as shown:

$$
\left(\frac{1 \mathrm{~g}}{\mathrm{~L}}\right)\left(\frac{1 \mathrm{~L}}{10^{3} \mathrm{ml}}\right)\left(\frac{0.0615 \mathrm{C}}{1 \mathrm{~g}}\right)\left(\frac{10^{6} \mu \mathrm{Ci}}{1 \mathrm{Ci}}\right)=61.5 \frac{\mu \mathrm{Ci}}{\mathrm{mL}}
$$

Agnew et al. (1996) notes that 88 percent of the flammable gas Watch List tanks have greater than 0.64 weight percent TOC in their sludges or concentrates. This suggests that tanks on the flammable gas Watch List will generally have a non-convective sludge layer approximately $4 \mathrm{~m}$ deep with a TOC value of 0.64 weight percent or greater and a supernate layer with a specific gravity of about 1.41 . Tank $241-\mathrm{AN}-106$ has a very shallow sludge layer (with an unknown TOC value) and a supernate density of only 1.19. Therefore, tank 241-AN-106 is predicted to be a poor candidate for the flammable gas Watch List.

\subsubsection{Verification of Tank Waste Classification}

The TOC analyses were performed in an effort to verify the waste type in tank 241-AN-106. Determining the waste type is important so that only compatible waste types are combined during transfers of waste into and within the double-shell tank system (Fowler 1995). Because the TOC analyses were not performed in support of tank safety issues, TOC was determined on only two grab samples (see Section 4.6 and Table 4-6). Unfortunately, without further characterization of the waste, the TOC value of $4,390 \mu \mathrm{g} \mathrm{C} / \mathrm{mL}$ could 
support a designation of either dilute complexed or dilute noncomplexed waste. Complexed waste is any waste that yields a TOC value of $\geq 10,000 \mu \mathrm{g} \mathrm{C} / \mathrm{mL}$ when concentrated almost to the point at which sodium aluminate precipitates (Fowler 1995, Hanlon 1996b). Information about the concentrations of aluminum, sodium, IC anions, carbonate (total inorganic carbon), and hydroxide are required to establish a waste designation (Allison 1984). 
WHC-SD-WM-ER-569 Rev. 0

This page intentionally left blank. 


\subsection{CONCLUSIONS AND RECOMMENDATIONS}

\subsection{CONCLUSIONS}

The waste in tank 241-AN-106 has been sampled and analyzed for safety screening according to the requirements listed in the Tank Safety Screening Data Quality Objective (Dukelow et al. 1995). The tank was grab sampled in April 1995 for process control purposes and in November 1995 for safety screening. The safety screening DQO required analyses for percent water, energetics, total alpha activity, and flammable gas to assess tank safety. Total organic carbon was determined in an attempt to verify the classification of the tank waste. All samples were analyzed at the 222-S Laboratory.

The November 1995 grab sampling event met the requirements of the safety screening DQO for the tank supernate and headspace; no safety screening DQO criteria were exceeded. No exothermic reactions were observed in the DSC analysis. The average percent water value by TGA was 76.6 percent. The total alpha activity overall mean was $<0.00684 \mu \mathrm{Ci} / \mathrm{mL}$, well below the $\mathrm{DQO}$ notification limit of $61.5 \mu \mathrm{Ci} / \mathrm{mL}$. Finally, the concentration of flammable gas in the tank headspace was 0 percent of the LFL. The sludge layer, which constitutes only four percent of the waste volume in tank 241-AN-106, could not be adequately sampled; therefore no assessment can be made for the sludge layer regarding the tank safety DQO.

Although no heat load estimates were available, it appears heat generation is not a problem because the tank exhibited its upper temperature extreme when waste was added to the tank in September 1994.

The mean TOC value for the supernate based on two November 1995 grab samples is 4,390 $\mu \mathrm{g} \mathrm{C} / \mathrm{mL}$ and could support a designation of dilute complexed or dilute noncomplexed waste. The additional information required to establish the waste designation are the concentrations of aluminum, sodium, the IC anions, carbonate (total inorganic carbon), and hydroxide. Based on analyses of samples from tank 241-AW-106 and the 242-A Evaporator 94-1 Campaign, which are the two major sources for the waste in tank 241-AN-106, the bulk of the organic carbon in the tank waste is likely to consist of organic complexing agents and their breakdown products. If the bulk of the TOC consists of complexing agents, then the waste would be designated as dilute conplexed.

The analytical results and tank surveillance data show the waste in tank 241-AN-106 as consisting of approximately $1,510 \mathrm{~kL}(398 \mathrm{kgal})$ of supernate with a tank heel of approximately 52 to $64 \mathrm{~kL}$ (14 to $17 \mathrm{kgal}$ ). The statistical results suggest that the supernate layer exhibits a slight vertical heterogeneity in weight percent water content. The tank shows a definite increase in the concentration of beta/gamma-emitting radionuclides with sample depth. Horizontally, the supernate appears to be fairly homogeneous. 
The available evidence based on the tank transfer history, sludge level measurements, and the visual description of the samples taken near the tank bottom imply that a sludge layer resides on the tank bottom. Evidence from sludge weight measurements and the attempts to grab sample the sludge layer indicates that the sludge layer is about 13 to $16 \mathrm{~cm}$ ( 5 to 6 in.) deep. The increase in radionuclide concentration with depth implies that the sludge layer is likely to have a greater radionuclide concentration than the supernate.

Mixing compatibility and boildown studies were conducted on mixtures of tank 241-AN-106 supernate from the April 1995 sampling event and supernate from tank 241-AY-101. Mixing 25:75 and 30:70 ratios of tank 241-AN-106:241-AY-101 supernates generated no major color changes, heat generation, foaming, precipitations, or obvious density differences. The 30:70 and 50:50 mixtures of tank 241-AN-106:241-AY-101 supernates had free-hydroxide values of $0.046 M(780 \mu \mathrm{g} / \mathrm{mL})$ and $0.197 M(3,350 \mu \mathrm{g} / \mathrm{mL})$ respectively. Differential scanning calorimetry scans to $500{ }^{\circ} \mathrm{C}$ of aliquots of the $25: 75$ and 30:70 mixtures revealed no exotherms; the only endotherm observerl was attributed to water loss. A boildown of a 30:70 mixture of tank 241-AN-106:241-AY-101 supernates yielded a final waste volume reduction of 76 percent. The final product of the boildown had a density of $1.55 \mathrm{mg} / \mathrm{L}$ and was a thick, orange-yellow, pourable sludge containing visible granular material and some clumps of stiff, nonpourable sludge.

Three tanks in the AN tank farm are on the flammable gas Watch List, but tank 241-AN-106 is not. The three AN tank farm tanks on the flammable gas Watch List have significant nonconvective sludge layers and supernate-specific gravities greater than 1.41. In contrast, tank 241-AN-106 has a very small sludge layer and a supernate layer with a density of only $1.19 \mathrm{~g} / \mathrm{mL}$.

\subsection{RECOMMENDATIONS}

Because tank 241-AN-106 is in active service, the tank contents are subject to change during future tank farm operations. Future operations will likely require analysis of the contents of tank 241-AN-106 for compatibility, and it is recommended that the existing grab samples be archived to avoid future expense in sampling the tank supernate. Additional analysis of the archived samples should provide most of the information required for any future tank farm operations involving tank 241-AN-106. However, this recommendation would be invalid if the contents of tank 241-AN-106 changed because of future additions of waste to the tank. Future additions of waste would change the composition of the waste and would require new samples be taken to address any future tank waste safety and compatibility issues. This recommendation also would be invalid if the samples remained in archival storage for more than one year because there would be no guarantee that the samples would remain representative after a long storage period. 
When the supernate contents of tank 241-AN-106 are completely emptied from the tank, and as program funding and priorities allow, the sludge heel in the tank should be auger sampled to complete the safety screening of the tank contents. Completion of the safety screening of the tank heel will confirm the safety status of the tank. 
WHC-SD-WM-ER-569 Rev. 0

This page intentionally left blank. 


\subsection{REFERENCES}

Agnew, S. F., P. Baca, R. Corbin, T. Duran, and K. Jurgensen, 1995, Waste Status and Transaction Record Summary for the Southeast Quadrant, WHC-SD-WM-TI-689, Rev. 1, Westinghouse Hanford Company, Richland, Washington.

Agnew, S. F., R. Corbin, J. Boyer, T. Duran, K. Jurgensen, T. Ortiz, B. Young, R. Anema, and C. Ungerecht, 1996, History of Organic Carbon in Hanford HLW Tanks: HDW Model Rev. 3, LA-UR-96-989, Los Alamos National Laboratory, Los Alamos, New Mexico.

Allison, J. M., 1984, Computer Predictions of Evaporator Operations, RHO-SD-WM-ADP-004, Rev. 0, Rockwell Hanford Operations, Richland, Washington.

Alstad, A. T., 1992, Riser Configuration Document for Double-Shell Waste Tanks, WHC-SD-RE-TI-093, Rev. 3, Westinghouse Hanford Company, Richland, Washington.

Beck, M. A., 1995, Results of Boildown and Mixing Studies on Tank AN-106 and Tank AY-101, (Letter 75980-PCS95-051 to J. M. Jones, July 28), Westinghouse Hanford Company, Richland, Washington.

Brevick, C. H., L. A. Gaddis, W. W. Pickett, 1995a, Historical Tank Content Estimate for the Southeast Quadrant of the Hanford 200 East Areas, WHC-SD-WM-ER-350, Rev. 0, Westinghouse Hanford Company, Richland, Washington.

Brevick, C. H., S. D. Consort, and L. A. Gaddis, 1995b, Supporting Document for the Historical Tank Content Estimate for AN Tank Farm, WHC-SD-WM-ER-314, Rev. 0, Westinghouse Hanford Company, Richland, Washington.

Brevick, C. H., S. D. Consort, and L. A. Gaddis, 1995c, Supporting Document for the Southeast Quadrant Historical Tank Content Estimate Report for AW Tank Farm, WHC-SD-WM-ER-316, Rev. 0, Westinghouse Hanford Company, Richland, Washington.

Conner, J. M., 1995, Tank 241-AN-106 Grab Sampling and Analysis Plan, WHC-SD-WM-TSAP-070, Rev. 0A, Westinghouse Hanford Company, Richland, Washington.

Cromar, R. D., 1996, Statistical Results for Double-Shell Tank AN-106, (Letter 75764-PCS96-047 to J. G. Douglas, May 15), Westinghouse Hanford Company, Richland, Washington. 
DeLorenzo, D. S., A. T. DiCenso, D. B. Hiller, K. W. Johnson, J. H. Rutherford, B. C. Simpson and D. J. Smith, Tank Characterization Reference Guide, WHC-SD-WM-TI-648, Rev. 0, Westinghouse Hanford Company, Richland, Washington.

DiCenso, A. T., L. C. Amato, J. D. Franklin, G. L. Nuttall, T. T. Tran, B. C. Simpson, 1994, Tank Characterization Report for Double-Shell Tank 241-AW-106, WHC-SD-WM-ER-365, Rev. 0, Westinghouse Hanford Company, Richland, Washington.

DOE, 1995, Hanford Analytical Services Quality Assurance Plan, DOE/RL-94-55, Rev. 2, U.S. Department of Energy, Richland, Washington.

Dukelow, G. T., H. Babad, J. W. Hunt, and J. E. Meacham, 1995, Tank Safery Screening Data Quality Objective, WHC-SD-WM-SP-004, Rev. 2, Westinghouse Hanford Company, Richland, Washington.

Ecology, EPA, and DOE, 1996, Hanford Federal Facility Agreement and Consent Order, as amended, Washington State Department of Ecology, U.S. Environmental Protection Agency, and U.S. Department of Energy, Olympia, Washington.

Esch, R. A., 1996a, 45-Day Safery Screening Results and Final Report for Tank 241-AN-106, Grab Samples 6AN-95-1 Through 6AN-95-9, WHC-SD-WM-DP-168, Rev. 0A, Westinghouse Hanford Company, Richland, Washington.

Esch, R. A., 1996b, Final Report for Tank 241-AY-101, Grab Samples 1AY-96-1 through 1AY-96-10 and 1AY-96-FB, WHC-SD-WM-DD-178, Rev. 1, Westinghouse Hanford Company, Richland, Washington.

Estey, S. D. and M. D. Guthrie, 1996, An Analysis of Parameters Describing Gas Retention/Release Behavior in Double Shell Tank Waste, WHC-SD-WM-TI-755, Rev. 0, Westinghouse Hanford Company, Richland, Washington.

Fowler, K. D., 1995, Tank Farm Waste Transfer Compatibility Program, WHC-SD-WM-OCD-015, Rev. 1, Westinghouse Hanford Company, Richland, Washington.

Guthrie, M. D., 1994, 242-A Campaign 94-1 Post-Run Document, WHC-SD-WM-PE-053, Rev. 0, Westinghouse Hanford Company, Richland, Washington.

Hanlon, B. M., 1994, Tank Farm Surveillance and Waste Tank Summary Report - July 1994, WHC-EP-0182-75, Westinghouse Hanford Company, Richland, Washington. 
Hanion, B. M., 1996a, Waste Tank Summary Report for Month Ending November 30, 1995, WHC-EP-0182-92, Westinghouse Hanford Company, Richland, Washington.

Hanlon, B. M., 1996b, Waste Tank Summary Report for Month Ending May 31, 1996, WHC-EP-0182-99, Westinghouse Hanford Company, Richland, Washington.

Harville, D. A., 1977, "Maximum Likelihood Approaches to Variance Component Estimation and to Related Problems," Joumal of the American Statistical Association, pp. $320-340$.

Johnson, M. G., 1995, Technical Bases for Leak Detection Surveillance of Waste Storage Tanks, WHC-SD-WM-TI-573, Rev. 1, Westinghouse Hanford Company, Richland, Washington.

Jones, R. A., 1995, Detection Limits and Uncertainty Calculations for Radioisotopic Counting, Analytical Services Laboratory Analytical Procedure LA-508-002, Rev. B-0, Westinghouse Hanford Company, Richland, Washington.

Le, E. Q., 1994, Process Control Plan for 242-A Evaporator Campaign 94-1, WHC-SD-WM-PCP-008, Rev. 1, Westinghouse Hanford Company, Richland, Washington.

Miller, G. L., 1996, Analyses and Characterization of 242-A Evaporator Slurry Campaign 94-1, WHC-SD-WM-DP-067, Rev. OB, Westinghouse Hanford Company, Richland, Washington.

NFPA, 1995, National Fire Codes, Vol. 10, Section 115, “Laser Fire Protection,” National Fire Prevention Association, Quincy, Massachusetts.

Snedecor, G. W. and W. G. Cochran, 1980, Statistical Methods, 7th Edition, Iowa State University Press, Ames, Iowa.

Statistical Sciences, 1993, S-PLUS Reference Manual, Version 3.2, Statistical Sciences, Inc., Seattle, Washington.

Welsh, T. L. and D. W. Hendrickson, 1991, Tank 241-AN-106 Characterization Results, WHC-SD-CP-TP-065, Rev. 0, Westinghouse Hanford Company, Richland, Washington.

WHC, 1994, “Piping Plan Tank 106," Drawing No. H-2-71996, Sh. 1, Rev. 7, Westinghouse Hanford Company, Richland, Washington.

WHC, 1995c, "241-AN-106 Perform Grab Samples," Work Package No. ES-94-01283, Westinghouse Hanford Company, Richland, Washington. 
WHC, 1995a, "Dome Penetration Schedules Tanks 101-107," Drawing No. H-14-010501, Sh. 3, Rev. 0, Westinghouse Hanford Company, Richland, Washington.

WHC, 1995b, "Plan Tank Penetrations 101-106," Drawing No. H-14-010501, Sh. 1, Rev. 2, Westinghouse Hanford Company, Richland, Washington.

WHC, 1995d, "Supernatant and Sludge Sampler," Drawing No. H-2-85602, Sh. 1, Rev. 0, Westinghouse Hanford Company, Richland, Washington.

WHC, 1996, Surveillance Analysis Computer System database, March 14, 1996, Tank Farm Surveillance Engineering, Westinghouse Hanford Company, Richland, Washington. 


\section{APPENDIX A \\ CALCULATED COMPOSITION OF TANK 241-AN-106 SUPERNATE}


WHC-SD-WM-ER-569 Rev. 0

This page intentionally left biank. 


\section{APPENDIX A}

\section{CALCULATED COMPOSITION OF TANK 241-AN-106 SUPERNATE}

\section{A.1 INTRODUCTION}

The waste in tank 241-AN-106 was generated in 1994 as a combination of supernate that was in tank 241-AW-106 and the final product from the 242-A Evaporator 94-1 Campaign. The supernate in tank 241-AW-106 was sampled in December 1993; the analytical data for that sample are reported in DiCenso et al. (1994). The final product from the 94-1 campaign was characterized as samples V97, V108, and V111 (Miller 1996).

The values from the tank 241-AW-106 and 94-1 campaign data sets were combined to estimate the contents of tank 241-AN-106 (see Table A-1). Table A-1 contains the following information: "AW-106," the results from the tank 241-AW-106 December 1993 sample; "V97," the results of the 94-1 campaign product; "Combined," the computed results from the two data sets; and "AN-106 Overall Mean," the results from the tank 241-AN-106 November 1995 grab samples. Section A.4 outlines the assumptions used to produce the values in the "Combined" column of Table A-1.

Because of uncertainties in assumptions underlying the computed composition data, the data in this appendix are for background information only; no decisions regarding the safety, handling, or treatment of the waste in tank 241-AN-106 should be based on the data reported in Appendix A.

\section{A.2 TANK 241-AW-106 SAMPLE RESULTS}

Table A-1 column "AW-106" contains an estimate of the tank 241-AW-106 supernate composition prior to the start of the 242-A Evaporator 94-1 Campaign (DiCenso et al. 1994). The estimate is based on an analysis of 20 supernate samples taken from tank 241-AN-106 in December 1993 and has been arithmetically corrected to account for the addition of tank 241-AW-102 supernate and water to tank 241-AW-106 prior to the start of the 94-1 campaign (Le 1994). The tank 241-AW-102 data are based on an analysis of eight samples taken from different depths down a single riser (Le 1994). The radionuclide and organic compound values in Table A-1 differ slightly from those listed in Table 2-3 of DiCenso et al. (1994) because the radionuclide and organic compound data in the DiCenso table were not corrected for the addition of tank 241-AW-102 supernate and water. In addition to the organic compounds listed in Table A-1, 2-hexanone $(0.031 \mu \mathrm{g} / \mathrm{mL})$, tridecane $(5.3 \mu \mathrm{g} / \mathrm{mL})$, and tetradecane $(4.4 \mu \mathrm{g} / \mathrm{mL})$ were detected in tank 241-AW-102 supernate but not in tank 241-AN-106 supernate. 
Table A-1. Tank 241-AN-106 Analyte Concentration Estimates Based on Tank Transfer History. (3 sheets)

\begin{tabular}{|c|c|c|c|c|}
\hline 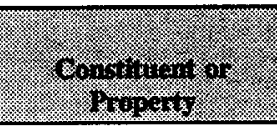 & 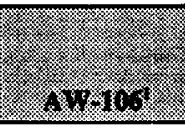 & 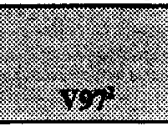 & continear & (1) \\
\hline Supernate volume (kL) & 440 & 1,160 & 1,600 & $\mathrm{n} / \mathrm{a}$ \\
\hline 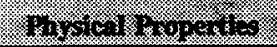 & (2:-2:- & (:) & (- & (2) \\
\hline Density & \multirow{2}{*}{$n / a$} & $1.192 \mathrm{~g} / \mathrm{mL}$ & \multirow{2}{*}{$\mathrm{n} / \mathrm{a}$} & $1.19 \mathrm{~g} / \mathrm{mL}$ \\
\hline Water & & $\mathrm{n} / \mathrm{a}$ & & $76.6 \mathrm{wt} \%$ \\
\hline (2): Mals: & (2) & 2.11: & 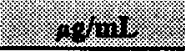 & miting \\
\hline Aluminum & 1,080 & 4,030 & 3,220 & \multirow{15}{*}{$n / a$} \\
\hline Arsenic & \multirow{12}{*}{$\mathrm{n} / \mathrm{a}$} & 5.85 & \multirow{12}{*}{$\mathrm{n} / \mathrm{a}$} & \\
\hline Barium & & $<0.25$ & & \\
\hline Cadmium & & 1.82 & & \\
\hline Calcium & & 9.29 & & \\
\hline Chromium & & 99.1 & & \\
\hline Iron & & 1.77 & & \\
\hline Lead & & $<7.00$ & & \\
\hline Magnesium & & $<5.32$ & & \\
\hline Manganese & & $<0.25$ & & \\
\hline Mercury & & $<0.005$ & & \\
\hline Selenium & & 0.168 & & \\
\hline Silver & & 2.82 & & \\
\hline Sodium & 27,100 & 94,000 & 75,600 & \\
\hline Zinc & $\mathrm{n} / \mathrm{a}$ & 2.17 & $\mathrm{n} / \mathrm{a}$ & \\
\hline 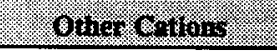 & kint: & gognting & (2) & eglint \\
\hline Ammonium & 89.6 & $<8,000$ & $<6,000$ & $n / a$ \\
\hline
\end{tabular}


Table A-1. Tank 241-AN-106 Analyte Concentration Estimates

Based on Tank Transfer History. (3 sheets)

\begin{tabular}{|c|c|c|c|c|}
\hline 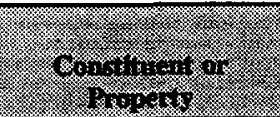 & 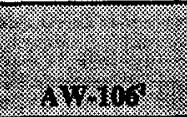 & $(2.25$ & 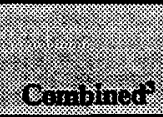 & 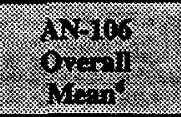 \\
\hline 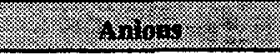 & (2. & 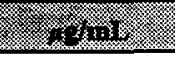 & (1., & 20 \\
\hline Chloride & \multirow{2}{*}{$n / a$} & 960 & \multirow{2}{*}{$\mathrm{n} / \mathrm{a}$} & \multirow{8}{*}{$\mathrm{n} / \mathrm{a}$} \\
\hline Cyanide & & 37.8 & & \\
\hline Fluoride & 4,780 & 5,230 & 5,110 & \\
\hline Hydroxide & 6,340 & 19,400 & 15,800 & \\
\hline Nitrate & 24,600 & 81,500 & 65,800 & \\
\hline Nitrite & 6,070 & 22,000 & 17,600 & \\
\hline Phosphate & 454 & 2,610 & 2,020 & \\
\hline Sulfate & 2,720 & 6,550 & 5,500 & \\
\hline (2. & 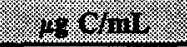 & 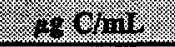 & $\left(x_{1} \cdot y_{1 i 13}\right.$ & 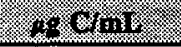 \\
\hline Total inorganic carbon & 308 & 5,910 & 4,370 & $\mathrm{n} / \mathrm{a}$ \\
\hline TOC & 728 & $2,600^{s}$ & 2,090 & 4,390 \\
\hline Acetone & $4.0 \mu \mathrm{g} / \mathrm{mL}$ & $\mathrm{n} / \mathrm{a}$ & $\mathrm{n} / \mathrm{a}$ & \multirow{3}{*}{$\mathrm{n} / \mathrm{a}$} \\
\hline Butanol & $0.055 \mu \mathrm{g} / \mathrm{mL}$ & $1.7 \mu \mathrm{g} / \mathrm{mL}^{\mathrm{s}}$ & $1.2 \mu \mathrm{g} / \mathrm{mL}$ & \\
\hline Tributyl phosphate & $\mathrm{n} / \mathrm{a}$ & $8.4 \mu \mathrm{g} / \mathrm{mL}^{5}$ & $\mathrm{n} / \mathrm{a}$ & \\
\hline 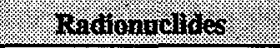 & avmi & (c) $12 m$ & iolni. & gormis \\
\hline Total alpha & \multirow{2}{*}{$\mathrm{n} / \mathrm{a}$} & $<0.023$ & \multirow{2}{*}{$\mathrm{n} / \mathrm{a}$} & $<0.00684$ \\
\hline Total beta & & 133 & & \multirow{7}{*}{$\mathrm{n} / \mathrm{a}$} \\
\hline${ }^{3} \mathrm{H}$ & 0.00778 & 0.00493 & 0.00571 & \\
\hline${ }^{14} \mathrm{C}$ & 0.0000368 & 0.000164 & 0.000129 & \\
\hline${ }^{80} \mathrm{Co}$ & $<0.00499$ & $<0.0248$ & $<0.0193$ & \\
\hline${ }^{79} \mathrm{Se}$ & 0.0000245 & 0.000126 & 0.0000981 & \\
\hline${ }^{90} \mathrm{Sr}$ & 0.0293 & 0.0420 & 0.0385 & \\
\hline${ }^{94} \mathrm{Nb}$ & $<0.00559$ & $\mathrm{n} / \mathrm{a}$ & $\mathrm{n} / \mathrm{a}$ & \\
\hline
\end{tabular}


Table A-1. Tank 241-AN-106 Analyte Concentration Estimates Based on Tank Transfer History. (3 sheets)

\begin{tabular}{|c|c|c|c|c|}
\hline 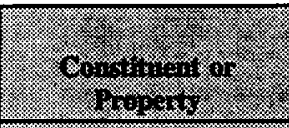 & 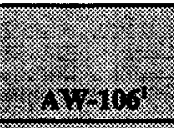 & (1) & 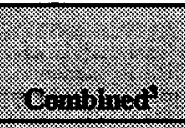 & 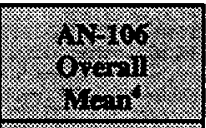 \\
\hline 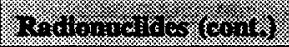 & 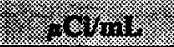 & 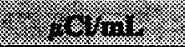 & 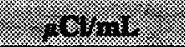 & 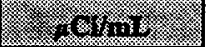 \\
\hline${ }^{96} \mathrm{Tc}$ & 0.00970 & 0.0278 & 0.0228 & \multirow{15}{*}{$\mathrm{n} / \mathrm{a}$} \\
\hline${ }^{106} \mathrm{Ru} /{ }^{106} \mathrm{Rh}$ & $<0.371$ & $<1.34$ & $<1.07$ & \\
\hline${ }^{113} \mathrm{Sn}$ & $<0.0340$ & $\mathrm{n} / \mathrm{a}$ & $\mathrm{n} / \mathrm{a}$ & \\
\hline${ }^{129} 1$ & $<0.0000209$ & $<0.0000339$ & $<0.0000303$ & \\
\hline${ }^{134} \mathrm{Cs}$ & 0.284 & 0.284 & 0.275 & \\
\hline${ }^{137} \mathrm{Cs}$ & 30.0 & 96.1 & 77.9 & \\
\hline${ }^{144} \mathrm{Ce}$ & $<0.185$ & $\mathrm{n} / \mathrm{a}$ & $\mathrm{n} / \mathrm{a}$ & \\
\hline${ }^{154} \mathrm{Eu}$ & $<0.0150$ & $<0.0742$ & $<0.0579$ & \\
\hline${ }^{155} \mathrm{Eu}$ & $<0.0476$ & $<0.181$ & $<0.144$ & \\
\hline${ }^{226} \mathrm{Ra}$ & $<0.146$ & $\mathrm{n} / \mathrm{a}$ & $\mathrm{n} / \mathrm{a}$ & \\
\hline Uranium (total) & $10.4 \mu \mathrm{g} / \mathrm{mL}$ & $21.9 \mu \mathrm{g} / \mathrm{mL}$ & $18.7 \mu \mathrm{g} / \mathrm{mL}$ & \\
\hline${ }^{238} \mathrm{Pu}$ & $\mathrm{n} / \mathrm{a}$ & $<0.000956$ & $\mathrm{n} / \mathrm{a}$ & \\
\hline${ }^{239,240} \mathrm{Pu}$ & 0.000167 & $<0.000652$ & $<0.000519$ & \\
\hline${ }^{241} \mathrm{Am}$ & $<0.0000670$ & $<0.00181$ & $<0.00133$ & \\
\hline${ }^{243 / 244} \mathrm{Cm}$ & $\mathrm{n} / \mathrm{a}$ & $<0.00181$ & $\mathrm{n} / \mathrm{a}$ & \\
\hline
\end{tabular}

Notes:

$\mathbf{n} / \mathbf{a}=$ not available

'From DiCenso et al. (1994)

${ }^{2}$ Evaporator sample number V97, from Miller (1996)

${ }^{3} \mathrm{See}$ accompanying text for discussion of how these values were generated.

${ }^{4} F r o m$ Section 4.0, this document

'Determined using evaporator sample V111 


\section{A.3 EVAPORATOR CAMPAIGN 94-1 SAMPLE RESULTS}

Waste characteristics and analytes determined for sample V97 include density, total inorganic carbon, hydroxide, cyanide, ion-chromatography anions, metals, and radionuclides. Volatile organic carbon was determined using sample V108 and TOC using sample V111. Analyses were performed using the 222-S Laboratory's standard quality assurance protocols; Miller (1996) reports the quality control results, and those are not included in Appendix A. For additional information, such as sample preparation and analytical method, refer to Miller (1996). The results reported in column "V97" are the average of a sample and duplicate determination for each analyte or property (the tritium results are an average of four determinations).

Because TOC and semi-volatile organic compounds were determined on sample V111, a comparison of the results is warranted. The TOC average value for this sample is $2,600 \mu \mathrm{g}$ $\mathrm{C} / \mathrm{mL}$. In addition to the butanol and tributyl phosphate results reported in Table A-1, a number of tentatively identified compounds were observed. These compounds included several aliphatic acids such as propanoic, butanoic, hexanoic, and heptanoic acids, and a number of unknown compounds. The largest reported concentration for any organic compound was an estimated $67 \mu \mathrm{g} / \mathrm{mL}$. Combining the results of all semi-volatile organic compounds detected falls far short of the TOC value of $2,600 \mu \mathrm{g} \mathrm{C} / \mathrm{mL}$. There are at least two possible explanations for this discrepancy: (1) most organic carbon is in a form that extracts poorly from the aqueous sample prior to analysis by gas chromatography/mass spectrometry, and/or (2) the organic carbon is insufficiently volatile to be determined by gas chromatography. Organic carbon in the form of ethylenediaminetetraacetic acid (EDTA), hydroxyethyl-ethylenediaminetriacetic acid (HEDTA), or large subfragments of those compounds frequently extract poorly and have boiling points too high for gas chromatography.

\section{A.4 METHOD AND ASSUMPTIONS FOR GENERATING COMBINED RESULTS}

The "Combined" column of Table A-1 was generated using the equation:

$$
\text { Combined }_{i}=\frac{\left(A W 106_{i} \times 440 \mathrm{~kL}\right)+\left(\mathrm{V} 97_{i} \times 1,160 \mathrm{~kL}\right)}{(440+1,160 \mathrm{~kL})}
$$

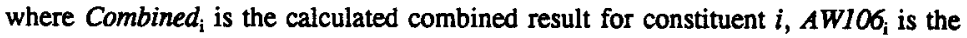
concentration of constituent $i$ from the tank $241-\mathrm{AW}-106$ results, and $V 97_{j}$ is the concentration of constituent $i$ from the campaign 94-1 V97 sample results. The value of $440 \mathrm{~kL}$ is the supernate volume that was in tank 241-AW-106 when the campaign 94-1 product was added to the tank (Hanlon 1994). The value of $1,160 \mathrm{~kL}$ is the volume of campaign 94-1 product added to tank 241-AW-106 (Guthrie 1994). 
The following assumptions were used in the model for the combined waste contents.

1. The tank 241-AW-106 supernate composition estimate shown in Table A-1 accurately reflects the contents of the tank when the 242-A Evaporator 94-1 Campaign product was added to the tank.

2. The densities of the tank 241-AW-106 contents and the 242-A Evaporator 94-1 Campaign product were identical so that the supernate volumes are additive.

3. The 242-A Evaporator 94-1 Campaign final product mixed completely with the tank 241-AW-106 supernate prior to transfer to tank 241-AN-106, but it had no interaction with the sludge layer in tank 241-AW-106.

4. Tank 241-AN-106 contained approximately $15 \mathrm{~kL}$ (4 kgal) of supernate prior to the transfer of waste from tank 241-AW-106 (Hanlon 1994). The contribution of this supernate heel to the "Combined" results was considered negligible.

The first assumption is not likely to be correct; tank 241-AW-106 was used as the receiver Luik for the 242-A Evaporator, and waste was cycled in and out of the tank several times during the 242-A Evaporator 94-1 Campaign (Guthrie 1994). The errors in the second assumption are probably outweighed by errors associated with the other assumptions.

The third assumption is difficult to assess. The degree of mixing will be related to the amount of convection that occurred as the 94-1 product was added to the tank, the density differences between the 94-1 product and the tank contents, and the amount of convection and diffusion mixing that occurred while the 94-1 product sat in tank 241-AW-106 for three months before being transferred to tank 241-AN-106. In view of these uncertainties, it is possible that mixing was complete prior to transfer to tank 241-AN-106, but the actual degree of mixing is unknown. Any interaction of the 94-1 product with the sludge layer in tank 241-AW-106, such as dissolution and transfer of constituents from the sludge layer to the supernate, is also unknown.

The fourth assumption should create little error in the "Combined" estimate because the $15 \mathrm{~kL}$ supernate heel in tank $241-\mathrm{AN}-106$ constituted only about one percent of the total waste volume after the waste transfer to the tank.

\section{A.5 COMBINED DATA CHARGE AND MASS BALANCES}

Having considered the limitations of the assumptions underlying the combined data set, it is still worthwhile to determine whether the data are consistent. One way to check the consistency is to perform charge and mass balance checks. 
The charge balance may be computed by summing the equivalent charge for the anions and cations, then taking the ratio of the cation and anion equivalent charges. The closer to unity the ratio is, the more consistent the data set. Table A-2 summarizes the charge balance information using data from the "Combined" column of Table A-1; only analytes with a concentration greater than or equal to $1000 \mu \mathrm{g} / \mathrm{mL}$ were used to perform the charge balance. As shown in Table A-2, aluminum is assumed to exist as aluminate, TIC as carbonate, and TOC as acetate; chloride and potassium are included as ions likely present in the supernate but for which the concentrations are unknown. The resulting charge balance ratio (cation/anion) for the data set is 1.07. Considering the assumptions underlying the data set, this is remarkably close to the ideal value of one, and indicates that most major analytes have been accounted for.

Table A-2. Charge Balance for Combined Analytical Data.

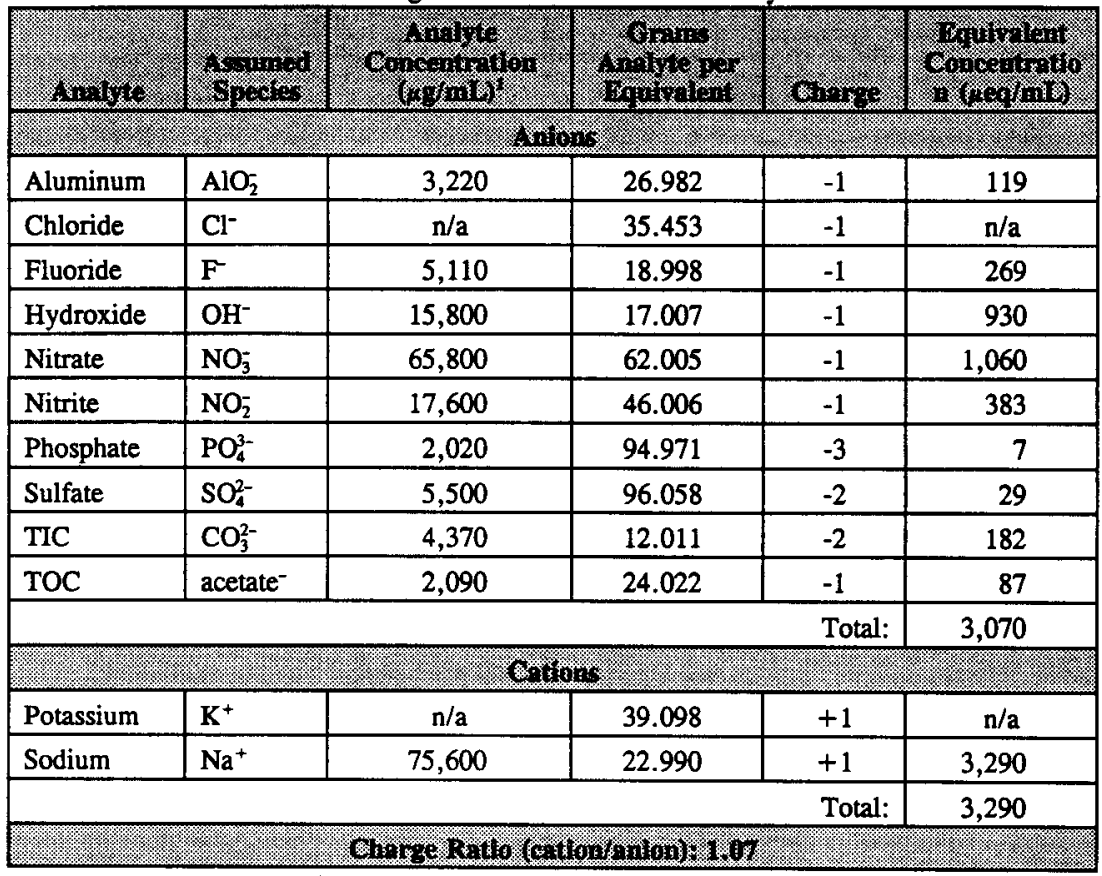

Notes:

$\mathrm{n} / \mathrm{a}=$ not available

'Table A-1 "Combined" column 
Once the major analytes are determined, it is useful to perform a mass balance using the major analytes as the contributors to the sample mass. What is not accounted for by the major analytes then determines an upper estimate for the water content in the material. Table A-3 shows the results of the mass balance calculations; the same assumptions applied to Table A-2 were applied to Table A-3. The resulting mass balance indicates that an upper estimate for water in tank $241-\mathrm{AN}-106$ supernate is 77.9 weight percent. Considering the assumptions underiying this value, the 77.9 weight percent value agrees remarkably well with the overall mean value of 76.6 weight percent from Table 4-4. 
Table A-3. Mass Balance for Combined Analytical Data.

\begin{tabular}{|c|c|c|c|c|}
\hline 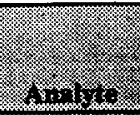 & 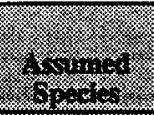 & 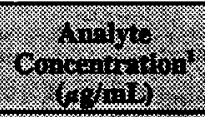 & 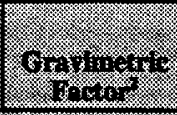 & 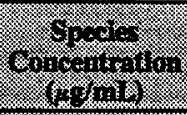 \\
\hline$x^{\prime}$ & & - in & & (2) \\
\hline Aluminum & $\mathrm{AlO}_{2}^{-}$ & 3,220 & 2.186 & 7,040 \\
\hline Chloride & $\mathrm{Cl}^{-}$ & $\mathrm{n} / \mathrm{a}$ & 1 & $\mathrm{n} / \mathrm{a}$ \\
\hline Fluoride & $\mathbf{F}^{-}$ & 5,110 & 1 & 5,110 \\
\hline Hydroxide & $\mathrm{OH}^{-}$ & 15,800 & 1 & 15,800 \\
\hline Nitrate & $\mathrm{NO}_{3}^{-}$ & 65,800 & 1 & 65,800 \\
\hline Nitrite & $\mathrm{NO}_{2}^{-}$ & 17,600 & 1 & 17,600 \\
\hline Phosphate & $\mathrm{PO}_{4}^{3-}$ & 2,020 & 1 & 2,020 \\
\hline Sulfate & $\mathrm{SO}_{4}^{2-}$ & 5,500 & 1 & 5,500 \\
\hline TIC & $\mathrm{CO}_{3}^{2-}$ & 4,370 & 5.00 & 21,800 \\
\hline TOC & acetate & 2,090 & 2.46 & 5,130 \\
\hline \multicolumn{4}{|c|}{ Anion mass total: } & 146,000 \\
\hline \multicolumn{5}{|c|}{ \% } \\
\hline Potassium & $\mathbf{K}^{+}$ & $\mathrm{n} / \mathrm{a}$ & 1 & $\mathrm{n} / \mathrm{a}$ \\
\hline Sodium & $\mathrm{Na}^{+}$ & 75,600 & 1 & 75,600 \\
\hline \multicolumn{4}{|c|}{ Cation mass total: } & 75,600 \\
\hline \multicolumn{4}{|r|}{ Mass total: } & 221,000 \\
\hline \multicolumn{4}{|r|}{ Missing mass: } & 779,000 \\
\hline \multicolumn{4}{|r|}{ Est. wt\% $\mathrm{H}_{2} \mathrm{O}$ : } & 77.9 \\
\hline
\end{tabular}

Notes:

$\mathbf{n} / \mathbf{a}=$ not available

'Table A-1 "Combined" column

'Gravimetric factor $=$ gram-formula weight of assumed species $\div$ gram-formula weight of analyte 
WHC-SD-WM-ER-569 Rev. 0

This page intentionally left blank. 
WHC-SD-WM-ER-569 Rev. 0

\section{APPENDIX B}

STATISTICAL RESULTS FOR DOUBLE-SHELL TANK 241-AN-106

B-1 
WHC-SD-WM-ER-569 Rev. 0

This page intentionally left blank.

B-2 


\section{APPENDIX B}

\section{STATISTICAL RESULTS FOR DOUBLE-SHELL TANK 241-AN-106'.}

\section{B.1 INTRODUCTION}

Appendix B provides the mean concentration and its associated variability for weight percent water, density, and TOC for the eight grab samples from tank 241-AN-106. This appendix also provides an analysis of variance (ANOVA) that shows the dependence of sample dose rate on sample depth.

The eight grab samples (bottle-on-a-string) were taken from each of two risers at specified depths. Dose rates were determined on these samples in the field prior to shipment to the 222-S Laboratory where the samples were chemically analyzed. Table B-1 shows the sample numbers, sample elevation, and analytical results for the samples. Analysis of variance techniques were used to analyze the following three properties of the samples: weight percent water, density, and TOC. Table B-2 summarizes the results from the ANOVA analysis and includes the mean concentration and its associated variability for the three properties. Section B.4 presents the sample dose rate data and the ANOVA for those data.

'This appendix is adapted from Cromar (1996). 
Table B-1. Weight percent Water, Density, and TOC Results for Tank 241-AN-106.

\begin{tabular}{|c|c|c|c|c|c|c|}
\hline and & $\frac{3}{3}$ & (3) & ist & 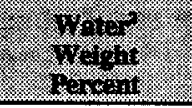 & 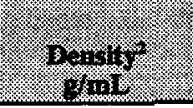 & 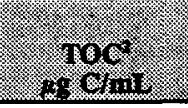 \\
\hline \multirow[t]{5}{*}{$22 \mathrm{~A}$} & \$96T000131 & 3.81 & (150) & $\mathrm{n} / \mathrm{a}$ & $\mathrm{n} / \mathrm{a}$ & $5370 \quad(4760)$ \\
\hline & S96T000136 & 3.81 & $(150)$ & $78.71 \quad(78.35)$ & 1.18 & $\mathrm{n} / \mathrm{a}$ \\
\hline & \$96T000137 & 2.03 & $(80)$ & $76.86 \quad(77.26)$ & 1.17 & $\mathrm{n} / \mathrm{a}$ \\
\hline & S96T000138 & 0.51 & $(20)$ & $76.56 \quad(75.48)$ & 1.18 & $\mathrm{n} / \mathrm{a}$ \\
\hline & S96T000140 & 0.13 & (5) & $75.32 \quad(73.71)$ & $(1.22)$ & $\mathrm{n} / \mathrm{a}$ \\
\hline \multirow[t]{5}{*}{$21 \mathrm{~A}$} & \$96T000152 & 0.13 & (5) & $\mathrm{n} / \mathrm{a}$ & $\mathrm{n} / \mathrm{a}$ & $3740 \quad(3700)$ \\
\hline & S96T000153 & 3.81 & $(150)$ & $77.76 \quad(77.92)$ & 1.16 & $\mathrm{n} / \mathrm{a}$ \\
\hline & S96T000154 & 2.03 & (80) & $79.37 \quad(77.14)$ & 1.18 & $\mathrm{n} / \mathrm{a}$ \\
\hline & S96T000155 & 0.51 & $(20)$ & $75.92 \quad(76.21)$ & 1.19 & $\mathrm{n} / \mathbf{a}$ \\
\hline & S96T000156 & 0.13 & (5) & $74.23 \quad(74.64)$ & (1.20) & $\mathrm{n} / \mathrm{a}$ \\
\hline
\end{tabular}

Notes:

$\mathbf{n} / \mathbf{a}=$ not applicable

'Sample elevation is measured from the tank bottom.

${ }^{2}$ Numbers in parentheses are for the duplicate.

Table B-2. Tank 241-AN-106 Summary Statistics.

\begin{tabular}{|c|c|c|c|}
\hline $8+11 / 1_{3} 6$ & 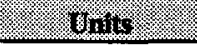 & $618=29$ & 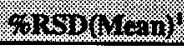 \\
\hline Water & Weight Percent & 76.59 & 1.10 \\
\hline Density & $\mathrm{g} / \mathrm{mL}$ & 1.18 & 0.63 \\
\hline TOC & $\mu \mathrm{g} \mathrm{C} / \mathrm{mL}$ & 4,393 & 15.31 \\
\hline
\end{tabular}

Note:

'Percent relative standard deviation of the mean is calculatod as $100 x$ standard deviation of the mean divided by the mean. 


\section{B.2 STATISTICAL ANALYSIS FOR PERCENT WATER, DENSITY, AND TOC}

A crossed-effects statistical model (Snedecor and Cochran 1980) was used to describe the structure of the data as follows.

$$
y_{i k x}=\mu+R_{i}+D_{j}+R D_{i j}+A_{i j k}
$$

where $\mathrm{i}=1,2, \mathrm{j}=1,2,3,4, \mathrm{k}=1,2$

$y_{i j}=$ laboratory result from the $\mathrm{k}^{\text {th }}$ duplicate of the $j^{\text {th }}$ depth of the $i^{\text {th }}$ riser from the tank

$\mu \quad=\quad$ the grand mean

$\mathbf{R}_{\mathbf{i}} \quad=$ the effect of the $i^{\text {th }}$ riser

$D_{j} \quad=\quad$ the effect of the $j^{\text {th }}$ depth

$\mathbf{R D}_{\mathrm{ij}}=$ the interaction of the $\mathrm{i}^{\mathrm{ith}}$ riser with the $\mathrm{j}^{\mathrm{t}}$ depth

$\mathrm{A}_{\mathrm{j} \mathrm{j}} \quad=$ the analytical variability associated with the $\mathrm{k}^{\text {th }}$ duplicate in the $\mathrm{j}^{\text {th }}$ depth from the $\mathrm{i}^{\mathrm{t}}$ riser.

Analysis of variance techniques were used with the above model to analyze the data. The variables $R_{i}, D_{j}$, and $R D_{i j}$ were assumed to be random effects. It is assumed that $R_{i}, D_{j}$, $\mathbf{R D}_{\mathrm{ij}}$, and $\mathrm{A}_{\mathrm{ij}}$ are uncorrelated and normally distributed with means zero and variances $\sigma^{2}(R)$, $\sigma^{2}(\mathrm{D}), \sigma^{2}(\mathrm{RD})$, and $\sigma^{2}(\mathrm{~A})$, respectively. Estimates of $\sigma^{2}(\mathrm{R}), \sigma^{2}(\mathrm{D}), \sigma^{2}(\mathrm{RD})$, and $\sigma^{2}(\mathrm{~A})$ were obtained using restricted maximum likelihood estimation (REML) techniques. This method applied to variance component estimation is described in Harville (1977). The statistical analysis package S-PLUS ${ }^{2}$ was used to obtain the REML results (Statistical Sciences 1993).

2S-PLUS is a registered trademark of MathSoft, Inc., Cambridge, Massachusetts. 
Because TOC analyses were not performed on all the samples (only one depth per riser), the statistical model for the ANOVA changes. The statistical model that describes the structure of these TOC data is as follows.

$$
\mathrm{y}_{\mathrm{ij}}=\mu+\mathrm{L}_{\mathrm{i}}+\mathbf{A}_{\mathrm{ij}}, \quad \mathrm{i}=1,2, \mathrm{j}=1,2
$$

where $y_{\mathrm{ij}}=$ laboratory result from the $\mathrm{j}^{\mathrm{th}}$ duplicate of the $\mathrm{i}^{\text {th }}$ location from the tank

$\mu \quad=$ the grand mean

$L_{i}=$ the effect of the $i^{\text {th }}$ location

$A_{i j}=$ the analytical variability associated with the $j^{\text {th }}$ duplicate from the $i^{\text {th }}$ location

The location variable $L_{i}$ is assumed to be a random effect. In addition, $L_{i}$ and $A_{i j}$ are assumed to be uncorrelated and normally distributed with means zero and variances $\sigma^{2}(\mathrm{~L})$ and $\sigma^{2}(\mathrm{~A})$, respectively. Estimates of $\sigma^{2}(\mathrm{~L})$ and $\sigma^{2}(\mathrm{~A})$ were obtained using REML techniques. This method applied to variance component estimation is described in Harville (1977). The statistical analysis package S-PLUS ${ }^{\circ}$ was used to obtain the REML results (Statistical Sciences 1993).

\section{B.3 RESULTS FOR PERCENT WATER, DENSITY, AND TOC}

The estimate of the mean concentration, $\hat{\mu}$, and the standard deviation of the mean, $\hat{\sigma}_{\hat{\mu}}$, were obtained from the ANOVA results. For the weight percent water and density data, the standard deviation of the mean, $\hat{\sigma}_{\hat{\mu}}$, is the square root of a linear combination of the variance estimates $\sigma^{2}(\mathrm{R}), \sigma^{2}(\mathrm{D}), \sigma^{2}(\mathrm{RD})$, and $\sigma^{2}(\mathrm{~A})$. For the TOC data, the standard deviation of the mean, $\hat{\sigma}_{\hat{\mu}}$, is the square root of a linear combination of the variance estimates $\sigma^{2}(L)$ and $\sigma^{2}(A)$. The mean concentration and the relative standard deviation of the mean, in percent, are listed in Table B-2. The relative standard deviation of the mean, in percent, is 100 times the standard deviation of the mean divided by the mean.

The variance components determined from the ANOVA are listed in Table B-3. An F-Test was performed to determine whether each variance component $\left(\sigma^{2}(R), \sigma^{2}(D), \sigma^{2}(R D)\right.$, and $\sigma^{2}(L)$ ) was significantly different from zero. The statistical tests use the mean square terms from the ANOVA results. The p-values are the attained level of significance of the statistical test. A p-value less than 0.05 indicates that the variance component is significantly different from zero at the 0.05 level of significance. If the variance component is significantly different from zero then the mean analyte concentrations are significantly different from each other. The p-values from the F-Tests are shown in Table B-4. The ANOVA tables with the expected mean squares for the three sample properties are shown in Tables B-5 through B-7. 
Table B-3. Tank 241-AN-106 Variance Component Estimates.

\begin{tabular}{|c|c|c|c|c|}
\hline (1) & \multicolumn{4}{|c|}{ 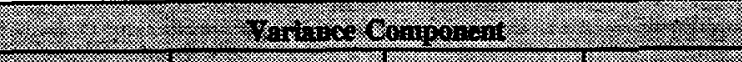 } \\
\hline (2) & sising & $\sin$ & 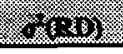 & 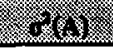 \\
\hline Weight percent water & $2.10 \mathrm{E}-30$ & $2.68 \mathrm{E}+00$ & $7.81 \mathrm{E}-19$ & $5.47 \mathrm{E}-01$ \\
\hline Density & $5.82 \mathrm{E}-23$ & $1.31 \mathrm{E}-04$ & $9.80 \mathrm{E}-05$ & $1.00 \mathrm{E}-04$ \\
\hline (2) & . & . & & \\
\hline TOC & 8.58E+05 & $9.34 \mathrm{E}+04$ & & \\
\hline
\end{tabular}

Table B-4. Variance Component Hypothesis Test Results.

\begin{tabular}{|c|c|c|c|}
\hline (1) & 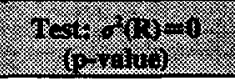 & 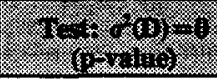 & 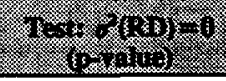 \\
\hline Weight percent water & NS $(0.79)$ & SIG $(0.02)$ & NS $(0.42)$ \\
\hline Density & NS $(0.57)$ & NS $(0.22)$ & NS $(0.38)$ \\
\hline iv. & (6) & & \\
\hline TOC & NS $(0.48)$ & & \\
\hline
\end{tabular}

Notes:

$$
\begin{array}{lll}
\text { NS } & = & \text { Not Significant } \\
\text { SIG } & = & \text { Significant }
\end{array}
$$

\begin{tabular}{|c|c|c|c|c|}
\hline . & 8 & 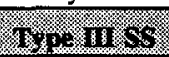 & 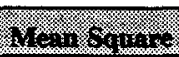 & 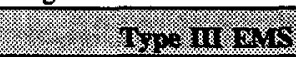 \\
\hline Riser & 1 & 0.055225 & 0.055225 & $\sigma^{2}(\mathrm{~A})+2 \sigma^{2}(\mathrm{RD})+8 \sigma^{2}(\mathrm{R})$ \\
\hline Depth & 3 & 33.826250 & 11.275417 & $\sigma^{2}(\mathrm{~A})+2 \sigma^{2}(\mathrm{RD})+4 \sigma^{2}(\mathrm{D})$ \\
\hline Riser * Depth & 3 & 1.857325 & 0.619108 & $\sigma^{2}(\mathrm{~A})+2 \sigma^{2}(\mathrm{RD})$ \\
\hline Error & 8 & 4.649400 & 0.581175 & $\sigma^{2}(\mathrm{~A})$ \\
\hline
\end{tabular}

Table B-5. Analysis of Variance Table for Weight Percent Water.

Notes:

$$
\begin{array}{lll}
\text { DF } & =\text { degrees of freedom } \\
\text { SS } & =\text { sum of squares } \\
\text { EMS } & =\quad \text { expected mean square }
\end{array}
$$


Table B-6. Analysis of Variance Table for Density.

\begin{tabular}{|c|c|c|c|c|}
\hline$(2.01020$ & 81 & $3 \times 1,13 / 25$ & 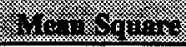 & 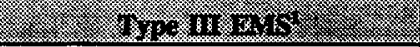 \\
\hline Riser & 1 & 0.0000893 & 0.0000893 & $\sigma^{2}(\mathrm{~A})+1.14 \sigma^{2}(\mathrm{RD})+4.57 \sigma^{2}(\mathrm{R})$ \\
\hline Depth & 3 & 0.0018350 & 0.0006117 & $\sigma^{2}(\mathrm{~A})+1.2 \sigma^{2}(\mathrm{RD})+2.4 \sigma^{2}(\mathrm{D})$ \\
\hline Riser * Depth & 3 & 0.0006750 & 0.0002250 & $\sigma^{2}(\mathrm{~A})+1.2 \sigma^{2}(\mathrm{RD})$ \\
\hline Error & 2 & 0.0002500 & 0.0001250 & $\sigma^{2}(A)$ \\
\hline
\end{tabular}

Notes:

$$
\begin{array}{ll}
\text { DF } & =\text { degrees of freedom } \\
\text { SS } & =\text { sum of squares } \\
\text { EMS } & =\text { expected mean square }
\end{array}
$$

'The EMS expressions and computations of the variance components and $p$ values are more complicated for the density data than for weight percent water because the density data are

\begin{tabular}{|c|c|c|c|c|}
\hline Sorins & 812 & $18.80 .81,054$ & 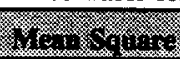 & 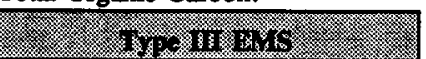 \\
\hline Riser & 1 & 1809025 & 1809025 & $\sigma^{2}(A)+2 \sigma^{2}(R)$ \\
\hline Error & 2 & 186850 & 93425 & $\sigma^{2}(\mathrm{~A})$ \\
\hline
\end{tabular}
"unbalanced," that is, duplicate density determinations were not performed for every sample.

Table B-7. Analysis of Variance Table for Total Organic Carbon.

Notes:

$$
\begin{array}{ll}
\text { DF } & =\text { degrees of freedom } \\
\text { SS } & =\text { sum of squares } \\
\text { EMS } & =\text { expected mean square }
\end{array}
$$

\section{B.4 STATISTICAL ANALYSIS AND RESULTS FOR SAMPLE DOSE RATE}

A one-way ANOVA was used to statistically examine the grab-sample contact dose rate data. Table B-8 shows the grab sample numbers, sample elevations, and contact dose rates for the data set. 
Table B-8. Sample Numbers, Sample Elevation, and Dose Rates for Tank 241-AN-106 Samples.

\begin{tabular}{|c|c|c|c|c|c|}
\hline$\sqrt{3.2}$ & 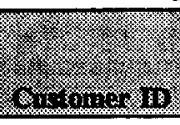 & 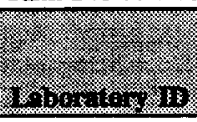 & 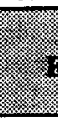 & tiv & 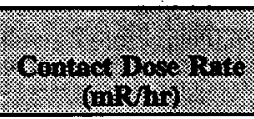 \\
\hline \multirow[t]{4}{*}{$22 \mathrm{~A}$} & 6AN-95-1 & S96T000131 & 3.81 & (150) & 250 \\
\hline & 6 AN-95-2 & S96T000132 & 2.03 & $(80)$ & 200 \\
\hline & 6 AN-95-3 & S96T000133 & 0.51 & (20) & 600 \\
\hline & $6 \mathrm{AN}-95-4$ & S96T000135 & 0.13 & (5) & 1,000 \\
\hline \multirow[t]{4}{*}{$21 \mathrm{~A}$} & 6 AN-95-5 & S96T000149 & 3.81 & (150) & 300 \\
\hline & $6 \mathrm{AN}-95-6$ & S96T000150 & 2.03 & $(80)$ & 250 \\
\hline & 6 AN-95-7 & S96T000151 & 0.51 & (20) & 500 \\
\hline & 6 AN-95-8 & S96T000152 & 0.13 & (5) & 800 \\
\hline
\end{tabular}

Notes:

'Esch (1996a)

${ }^{2}$ Sample elevation is measured from the tank bottom.

The following model was used to describe the structure of the data.

$$
y_{i j}=\mu+D_{i}+\epsilon_{i j}
$$

where: $\mathrm{i}=1,2,3,4 ; \mathrm{j}=1,2$

$$
\begin{aligned}
& y_{i j}=\text { dose rate measurement for the } i^{\text {th }} \text { sample from the } j^{\text {th }} \text { riser } \\
& \mu=\text { the grand mean } \\
& D_{i}=\text { the effect of the } i^{\text {ih }} \text { sample elevation } \\
& \epsilon_{i j}=\text { residual error }
\end{aligned}
$$

This model assumes no effects arise from the riser that is sampled. This is a reasonable assumption based on the ANOVA results for the weight percent water, density, and TOC data and based on a visual examination of the dose rate data. 
Table B-9 shows the results of the one-way ANOVA. As with the ANOVA of the weight percent water, density, and TOC, a p-value was calculated and compared to 0.05 ; the p-value of 0.0038 from Table B-9 indicates that sample elevation is a significant factor in sample dose rate. To determine which samples differed significantly from each other, two multiple comparison tests were performed, Scheffe's Least Significant Difference test and Tukey's Studentized Range test. The two tests allow the sample analyte means to be sorted into significantly different groups. A value of 0.05 was chosen as the level of significance for comparing the dose rate means. Table B-10 presents the results of the dose rate groupings as determined by these two tests. Sample means with the same letter are not significantly different. Note that Tukey's test tends to generate more conservative groupings than the Least Significant Difference test.

Table B-9. Analysis of Variance Table for Sample Contact Dose Rate.

\begin{tabular}{|c|c|c|c|c|c|}
\hline 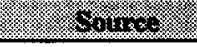 & $8 \mathrm{n}$ & 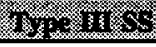 & 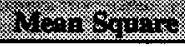 & $8 \times 1$, & P Taine \\
\hline Model & 3 & 576250 & 192083.33 & 27.94 & 0.0038 \\
\hline Error & 4 & 27500 & 6875.00 & & \\
\hline Corrected Total & 7 & 603750 & & & \\
\hline
\end{tabular}

Notes:

$\begin{array}{lll}\text { DF } & = & \text { degrees of freedom } \\ \text { SS } & = & \text { sum of squares }\end{array}$

Table B-10. Groupings of Sample Dose Rate vs. Sample Elevation.'

\begin{tabular}{|c|c|c|c|}
\hline 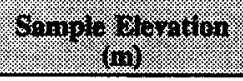 & 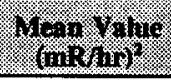 & 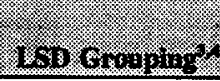 & Wurcy cromping? \\
\hline 3.81 & 275 & A & A \\
\hline 2.73 & 225 & A & A \\
\hline 0.51 & 550 & B & A \\
\hline 0.13 & 900 & C & B \\
\hline
\end{tabular}

Notes:

' $\alpha$ (level of significance) $=0.05$, degrees of freedom $=4$, mean squared error $=6875$

${ }^{2}$ Number of measurements for each mean $=2$

${ }^{3} \mathrm{Mean}$ values with the same letter are not significantly different.

${ }^{4}$ Critical value of $\mathrm{T}=2.78$, least significant difference $=230.21$

${ }^{s}$ Critical value of Studentized range $=5.757$, minimum significant difference $=337.54$ 
DISTRIBUTION SHEET

\begin{tabular}{|c|c|c|c|c|c|}
\hline To & \multirow{2}{*}{\multicolumn{3}{|c|}{$\begin{array}{c}\text { From } \\
\text { Data Assessment and } \\
\text { Interpretation }\end{array}$}} & \multicolumn{2}{|l|}{ Page 4 of 4} \\
\hline Distribution & & & & Date & $07 / 22 / 96$ \\
\hline \multirow{2}{*}{\multicolumn{4}{|c|}{$\begin{array}{l}\text { Project Title/Work Order } \\
\text { Tank Characterization Report for Double-She11 Tank 241-AN-106. } \\
\text { WHC-SD-WM-ER-569. Rev. } 0\end{array}$}} & \multicolumn{2}{|c|}{ EDT No. EDT-617508 } \\
\hline & & & & \multicolumn{2}{|c|}{ ECN No. N/A } \\
\hline Name & MSIN & $\begin{array}{l}\text { Text } \\
\text { With All } \\
\text { Attach. }\end{array}$ & Text Only & $\begin{array}{l}\text { Attach./ } \\
\text { Appendix } \\
\text { Only }\end{array}$ & $\begin{array}{c}\text { EDT/ECN } \\
\text { Only }\end{array}$ \\
\hline
\end{tabular}

Westinghouse Hanford Company continued

W. C. Miller

C. T. Narquis

D. E. Place

D. A. Reynolds

L. M. Sasaki (2)

L. W. Shelton, Jr.

B. C. Simpson

G. L. Troyer

L. R. Webb

K. A. White

FFIC (Tank Farm Information Genter) Central Files

EDMC

ERC (Environmental Resource Center) $\longrightarrow$

TCRC (10)
R1-56 X

T6-16

H5- 27

R2-11

R2 - 12

H5-49

R2-12

T6-50

T6-06

S5-13

20

A3- 88

H6- 08

R1-51

A3-36-

R2-12

$x$
$x$

$x$

$x$

$x$

$x$

$x$

$x$

$x$

$x$

$\hat{x}$

$x$ $x_{x}^{x} G-11$ 


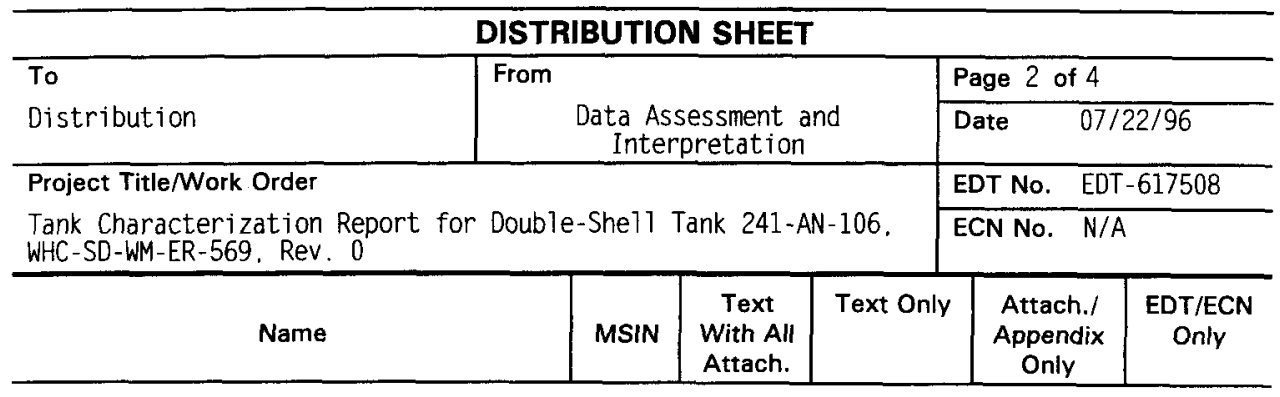

SAIC

20300 Century Boulevard. Suite 200-B

Germantown, MD 20874

H. Sutter

555 Quince Orchard Rd. . Suite 500

Gaithersburg, MD 20878

P. Szerszen

LOS Alamos Laboratory

CST-14 MS-J586

P. 0 . Box 1663

Los Alamos. NM 87545

S. F. Agnew (4)

Los Alamos Technical Associates

T. T. Tran

B1-44 X

Ogden Environmental

101 East Wellsian Way

Richland. WA 99352

R. J. Anema

$\mathrm{CH} 2 \mathrm{M} \mathrm{Hil]}$

P. O. Box 91500

Bel levue, WA 98009-2050

M. McAfee

$x$

Tank Advisory Panel

102 Windham Road

Oak Ridge. TN 37830

D. 0. Campbe11

$x$ 
DISTRIBUTION SHEET

\begin{tabular}{|c|c|c|c|c|c|}
\hline \multirow{2}{*}{$\begin{array}{l}\text { To } \\
\text { Distribution }\end{array}$} & \multirow{2}{*}{\multicolumn{3}{|c|}{$\begin{array}{l}\text { Data Assessment ar } \\
\text { Interpretation }\end{array}$}} & \multicolumn{2}{|l|}{ Page 3 of 4} \\
\hline & & & & Date & $07 / 22 / 96$ \\
\hline \multicolumn{4}{|l|}{ Project Title/Work Order } & \multicolumn{2}{|c|}{ EDT No. EDT-617508 } \\
\hline \multicolumn{4}{|c|}{$\begin{array}{l}\text { Tank Characterization Report for Double-Shel1 Tank 241-AN-106, } \\
\text { WHC-SD-WM-ER-569, Rev. } 0\end{array}$} & \multicolumn{2}{|l|}{ ECN No. $\quad N / A$} \\
\hline Name & MSIN & $\begin{array}{c}\text { Text } \\
\text { With All } \\
\text { Attach. }\end{array}$ & Text Only & $\begin{array}{l}\text { Attach./ } \\
\text { Appendix } \\
\text { Only }\end{array}$ & $\begin{array}{l}\text { EDT/ECN } \\
\text { Only }\end{array}$ \\
\hline
\end{tabular}

ONSITE

Department of Energy - Richland Operations

J. F. Thompson

W. S. Liou

N. W. Willis

S7-54 $\quad x$

$57-54 \quad x$

$57-54 \quad x$

ICF-Kaiser Hanford Company

R. L. Newel1

S3-09 $\quad x$

Pacific Northwest Laboratory

N. G. Colton

* J. R. Gormsen

S. A. Hartley

J. G. $\mathrm{Hill}$

G. J. Lumetta

A. F. Noonan

\section{Westinghouse Hanford Company}

H. Babad

D. A. Barnes

G. R. Bloom

W. L. Cowley

L. A. Diaz

J. G. Douglas

G. L. Dunford

* E. J. Eberlein

D. B. Engelman

J. S. Garfield

*J. D. Guberski

D. L. Herting

D. C. Hetzer

G. Jansen

G. D. Johnson

T. J. Kelley

N. W. Kirch

M. J. Kupfer

J. E. Meacham

* Aduanced Dist Dena
K3-75 $\quad X$

K $7-28$

$\mathrm{K} 5-12$

K7-94

P7-25

K9-81

S7-14

R1-80

H5-61

A3-37

T6-06

R2-12

A2 -34

R2-12

RI -49

H5- 49

R1-51

T6-09

S6-31

H6-33

S7 -15

S7-21

R2-11

H5- 49

S7-15 $x$

$x$ 


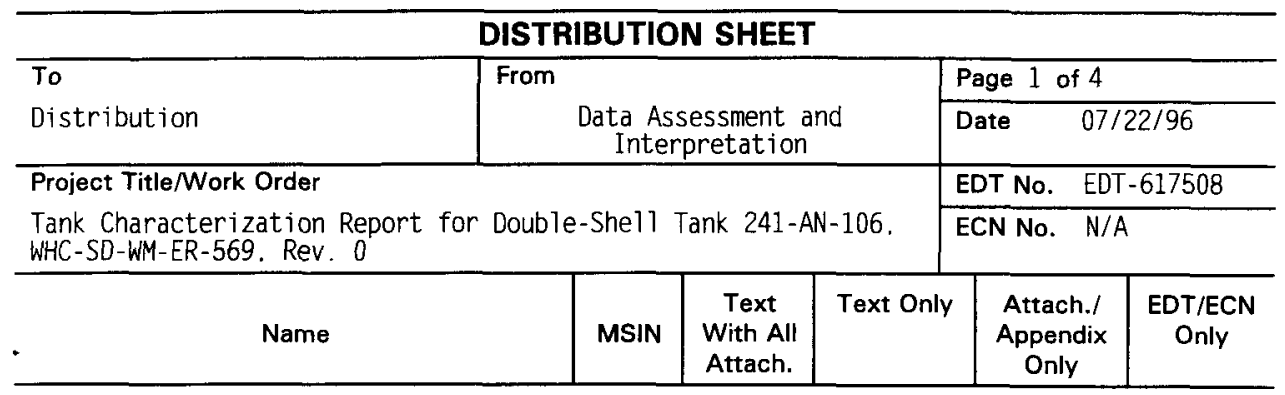

OFFSITE

Sandia National Laboratory

P.0. Box 5800

MS-0744. Dept. 6404

Albuquerque, NM 87815

D. Powers

$x$

Nuclear Consulting Services Inc.

P. O. Box 29151

Columbus, $\mathrm{OH}$ 43229-01051

J. L. Kovach

$x$

Chemical Reaction Sub-TAP

P.0. Box 271

Lindsborg. KS 67456

B. C. Hudson

$X$

Tank Characterization Panel

Senior Technical Consultant

Contech

7309 Indian School Road

A1buquerque. NM 87110

J. Arvisu

$x$

U. S. Department of Energy - Headquarters

Office of Environmental Restoration and Waste Management EM-563 12800 Middlebrook Road

Germantown. MD 20874

J. A. Poppitti

$x$

Jacobs Engineering Group

B5-36

$X$ 